\title{
Antiguos orígenes cristianos del actual concepto de religión
}

\author{
Ancients Christians Origins of the \\ Modern Concept of Religion
}

\author{
Pedro Giménez de Aragón Sierra \\ Universidad Pablo de Olavide. Sevilla. España \\ pgimsie@upo.es \\ ID ORCID 0000-0002-2412-9015
}

\begin{abstract}
Resumen: Este artículo se apoya en los estudios realizados en las últimas décadas respecto a la categoría conceptual de religión (Smith, Asad, Sachot, Martin, Boyarin, Barton), pero defiende una postura novedosa al respecto: aunque la evolución histórica de la palabra religio fue paulatina, el cambio conceptual comenzó ya con la traducción de la Vetus Latina. Por otra parte, sin menoscabar el papel de Lactancio, reivindicado por la investigación desde antiguo, se analiza aquí la importancia de su maestro Arnobio y de San Jerónimo.
\end{abstract}

Palabras claves: Religión, superstición, Vetus Latina, Arnobio, San Jerónimo.

\begin{abstract}
This article is suported on the research carried out in recent decades about the conceptual category of religion (Smith, Asad, Sachot, Martin, Boyarin, Barton), but it defends a novel position in this regard: although the historical evolution of the word religio was gradual, the conceptual change began with the traduction of Vetus Latina. On the other hand, without undermining the role of Lactantius, claimed by research since a long time, the importance of his teacher Arnobius and Saint Jerome is analyzed here.
\end{abstract}

Keywords: Religion, superstition, Vetus Latina, Arnobio, Saint Jerome.

Religio appellata, quod per eam uni Deo religamus animas nostras ad cultum divinum vinculo serviendi. Quod verbum conpositum est a relegendo, id est eligendo, ut ita Latinum videatur religio sicut eligio. Tria sunt autem quae in religionis cultu ad colendum Deum in hominibus perquiruntur, id est fides, spes, caritas. In fide, quid credendum; in spe, quid sperandum; in caritate, quid sit amandum, decía san Isidoro de Sevilla. ${ }^{1}$ Se aprecia en

1 “La religión recibió este nombre porque, mediante ella, «religamos» nuestras almas al único Dios para rendirle culto por el vínculo de servicio con Él establecido. Este vocablo se ha formado a partir de «re-elegir», es decir, de «elegir», 
este interesantísimo párrafo cómo el arzobispo hispalense jugaba con la palabra "religión" demostrando que conocía el significado ciceroniano, vinculado con el término "culto" —al que aludió dos veces-, así como la tardía teoría de Lactancio que en el siglo IV d.C. relacionó por primera vez el sustantivo con el verbo "religar", para finalmente acuñar una interpretación novedosa del origen etimológico del término relacionándolo con la acción de "elegir" (eligendo, eligio). El carácter electivo e individual de la decisión de profesar una religión, desvinculaba al término del matiz cívico, étnico o público que tenía antes del cristianismo. Además, san Isidoro relacionaba la religión claramente con"creencias" (quid credendum) y prácticas éticas (quid sit amandum), además de con el culto o ritual, ya mencionado. Se trata, pues, de una definición muy similar a la que hoy día se otorga en las lenguas occidentales a la palabra "religión": creencias y prácticas éticas y rituales vinculadas con lo metafísico. En consecuencia, no se puede seguir afirmando que la moderna categoría conceptual de "religión" surgió en la Edad Moderna. ${ }^{2}$ También el proceso por el cual se llega al concepto isidoriano del siglo VI d.C. está sujeto a debate y la investigación reciente continúa enriqueciéndonos.

de manera que, en latín, «religión» viene a ser «elección». Tres cosas se requieren en el hombre para dar culto a Dios en la práctica de la religión, a saber: fe, esperanza y caridad. En la fe se encuentra qué es lo que hay que creer; en la esperanza, qué es lo que hay que esperar; y en la caridad, qué es lo que hay que amar". Traducción de José Oroz y Manuel-A. Marcos, en San Isidoro de Sevilla, Etimologías, Madrid, Biblioteca de Autores Cristianos, 2018, 678-679.

2 Algunos autores, cuyos trabajos fueron pioneros en la reflexión al respecto y por tanto merecen el máximo de los respetos, consideraron como origen del sentido moderno de religio las siguientes obras: Pedro CIEZA DE LEÓN, Crónica del Perú, 1553; Richard Eden, A Treatyse of the Newe India, 1553; Edward BREREwOOD, Enquiries Touching the Diversity of Languages and Religions through the Chief Parts of the World, 1614; Edward HerberT, Sobre las religiones de los gentiles, Amsterdam, 1663. Entre dichos autores cabe destacar a Wilfred Cantwell SMITH, The Meaning and End of Religion: A New Approach to the Religious Traditions of Mankind, Nueva York, Macmillan Co., 1963; Jonathan SмIтH, "Religion, Religions, Religious", en M. C. TAYLor (ed.), Critical Terms for Religious Studies, Chicago, University of Chicago Press, 1998, 269-284; Talad AsAD, Genealogies of Religion, Baltimore Londres, The Johns Hopkins University Press, 1993, 40 y 53-54. 


\section{EVOLUCIÓN DE LA PALABRA RELIGIO EN LA ROMA REPUBLICANA Y DEL ALTO IMPERIO}

La palabra religio no existía en latín arcaico, según se desprende de las evidencias que a continuación se desarrollarán. No había en el lenguaje indoeuropeo un término para designar al ya mencionado sistema de ideas y normas rituales y éticas, como ya señaló hace tiempo Emile Benveniste. ${ }^{3}$ Tampoco existía en griego, ni en hebreo, ni en árabe, ni en sánscrito, ni en chino (lenguas que importarían el concepto desde el mundo occidental a partir del siglo V d.C., llegando al Extremo Oriente a finales de la Edad Moderna). Hasta ese momento, en todas las civilizaciones existían dos categorías diferentes para definir lo que hoy entendemos por "religión": una que se refería a las prácticas rituales vinculadas con lo metafísico, y otra que aludía a las creencias o ideas filosóficas respecto a lo metafísico y lo ético. Lo corriente, en el mundo romano y en las otras civilizaciones, hasta que surgió la actual categoría conceptual, era que para definir este último aspecto se utilizara una palabra similar a "filosofía". ${ }^{4}$

La palabra religio está compuesta de la raíz -lig-, el prefijo re- que indica repetición y el sufijo de sustantivos -io/-ionis. La raíz -lig- o -leg- estaba en primer lugar vinculada al verbo legere, "coger", "elegir", que a partir de la alfabetización de los latinos en los siglos VI-V a.C. se utilizaría también para "leer". Añadiéndole prefijos surgirían los verbos relegere, religere, intellegere, intelligere, neglegere y diligere. Como Benveniste argumentó, religio no procede de religare, como dijo Lactancio, porque los verbos de la primera conjugación no forman sustantivos abstractos en -io, sino en -atio, es decir, que de religare habría surgido religatio. Quizás san Isidoro apreció la contradicción gramatical de Lactancio y por ello buscó un nuevo origen etimológico acorde con su concepción del término. El participio agente de los verbos mencionados dio lugar a adjetivos que designaban a

3 Emilie Benveniste, Vocabulario de las instituciones indoeuropeas, vol. II, Madrid, Taurus, 1983 (orig. Paris 1969), 265-279.

4 Hasta 1787, por ejemplo, no existía la palabra "Hinduismo", mientras que el término "Budismo" se acuñó en 1801; hasta entonces se hablaba en Asia de "filosofías" hindú o de Buda, término que tiende a imponerse al de"religiones" desde hace años en un mundo postcolonial. Brent NongBri, Before Religion: A History of a Modern Concept, New Haven - Londres, Yale University Press, 2013, 1-2 y 25-64. 
personas inteligentes, diligentes y negligentes. Sin embargo, de religere, que significaría en origen "coger o elegir una y otra vez", en lugar del participio agente religens, surgiría otro tipo de adjetivo: religiosus. Lo contrario de negligens no sería religiosus, sino diligens. Y tenemos constancia por Plauto (254-184 a.C.) de que el sentido más antiguo del término religiosus era de carácter peyorativo y se usaba como sinónimo de "escrupuloso", "excesivamente obsesionado con los tabúes". ${ }^{5}$ Es interesante, en este sentido, el fragmento del discurso de Catón el Viejo (234-149 a.C.) contra Cornelio: “ ¿Hay alguien más inculto, más religioso, más desolador y más repulsivo para los asuntos públicos?". ${ }^{6}$

La primera vez que aparece en latín la palabra religio vinculada al culto a los dioses es probablemente en el poema Euhemerus de Quinto Ennio (239-169 a.C.), dedicado al filósofo greco-siciliano que degradó a los dioses a la categoría de reyes y héroes de la antigüedad más remota, divinizados por sus súbditos. Concretamente aparece en el pasaje en que el rey Júpiter decretó los rituales que debían celebrarse en su propio honor:"tanto para que a él se le rindieran honores divinos como para que sus anfitriones adquirieran una fama perpetua unida a su religio". ${ }^{7}$ Hay que tener en cuenta que Ennio nació en Rudias, Calabria, y que, antes que el latín, dominó el griego (y el osco), por lo que probablemente utilizó el término religio para

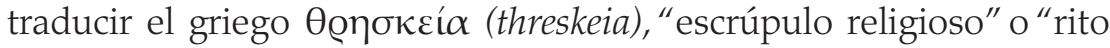
religioso escrupulosamente desempeñado". Dada la filosofía escéptica de Ennio y Evémero (330-250 a.C.), es obvio que tanto la palabra latina como la griega debían tener connotaciones peyorativas. Sin embargo, una diferencia parece apreciarse entre ambos términos en este momento: que religio aún no contenía el matiz de "cultos foráneos" que sí tendría threskeia en griego ático, como posteriormente se analizará.

Terencio (195-159 a.C.) también utilizó la palabra religio en un pasaje de su drama Andria para ridiculizar a un individuo demasiado timorato; sin embargo, en otro lugar de la misma obra en que calificó como religio los escrúpulos de un soldado respecto de usar dos tablas de un altar para hacer una cama, el interlocutor del soldado

Plauto, Curculium, 349-350; Assinaria, 781-783.

CATón, Contra Cornelium ad populum, fr. 194 (traducción propia).

EnNio, Fragmentos, 123; traducción de Juan MARTos, Madrid, Gredos, 2008. 
mostraba cierto respeto por dicho tabú, con lo cual aquí ya no tiene un sentido peyorativo; mientras que en su obra Heautontimorumenos usó la palabra en un contexto que nada tiene que ver con lo divino: "es una religio para mí decir que no tengo dinero". ${ }^{8}$ Obviamente, para Terencio significaba poco más que tabú, adquiriendo matices peyorativos, positivos o neutros según las circunstancias. En fragmentos de dramas de Livio Accio (170-86 a.C.), aparece tanto la vinculación de religio y religiosus con los rituales, como con "escrúpulo", sin perderse en cualquier caso el matiz peyorativo. ${ }^{9}$ Aunque el término experimentase un cambio en las épocas posteriores y se vinculase cada vez más al mundo de lo divino, todavía se usaría durante siglos con el simple sentido de "escrúpulo": un iudex religiosus, por ejemplo, sería un juez escrupuloso y por tanto diligente. En el siglo III d.C. Gayo Julio Solino todavía lo usaba en este sentido no vinculado con lo divino, diciendo que antes de abandonar su descripción de Escitia, sería una religio pasar por encima de las peculiaridades de su fauna. ${ }^{10}$

Como han destacado Barton y Boyarin, el sentido originario de la palabra religio, al igual que el de threskeia, sería similar al de la palabra indonesia "tabú", ya que estaba claramente relacionada en latín con timor, pudor y metus, es decir, con el miedo a realizar algún tipo de transgresión - tanto relacionada con lo divino como vinculada a cualquier tipo de actividad de la vida cotidiana-, lo que lleva a estos autores a definir el sentido primigenio de religio como"todo tipo de acción realizada con vigilante cuidado y concentración", un sentido que se conserva actualmente en inglés (y en español): "ella se lavó los dientes religiosamente", "él hizo sus tareas religiosamente". ${ }^{11}$

Hay que destacar lo que dijo Nigidio Fígulo ( $98-45$ a.C.) respecto al carácter negativo del adjetivo: que era bueno ser religente pero no religiosus, porque los sufijos en -osus/-osa indicaban exceso, y por tanto una persona "religiosa" era la que realizaba demasiados ritos y

8 Cf.Terencio, Andria, 722-730 (escrúpulo respetable) y 940-941 (escrúpulo ridículo); Heautontimorumenos, 228 (traducción propia).

9 Cf. Accio, fr. 171 = fr. 5 de la tragedia Astyanax; fr. 421 de Melanippus.

10 Cf. Solino, Collectanea rerum memorabilia, 19.9.

11 Cf. Carlin Barton - Daniel Boyarin, Imagine No Religion, New York, Fordham University Press, 2016, 20-27. Citan como ejemplos del uso de religio en el sentido de tabú los siguientes pasajes: Festo, p. 468, Cicerón, De legibus, 2.22.1; Plinio, Naturalis Historia, 28.7.39; CÉSAR, De Bello Gallico, 6.37; CATÓN el VIejo, Oratio uti praeda in publicum referatur; VIRGILIO, Georgica, 1.269; TITO Livio, Ab Urbe condita, 6.27.4-5; TÁcito, Historiae, 1.89; Aulo Gelio, Noctes Atticae, 10.15.3-4 y 24-25. 
actuaba de forma excesivamente escrupulosa con respecto a la divinidad, lo cual equivalía a superstitiosa. ${ }^{12}$ Superstes se traduce como "que está sobre", "presente", "superviviente" y, en ocasiones, como "adivino".

El filósofo epicúreo Lucrecio (99-55 a.C.), citado por Servio, explicaba la etimología de superstitio por el hecho de que se tratase de prácticas rituales sobre lo que está por encima de nosotros, lo celestial, añadiendo además el carácter "superfluo" de las mismas como posible explicación. ${ }^{13}$ Lucrecio, al igual que Nigidio Fígulo, consideraba sinónimos superstitiosus y religiosus, calificativos ambos que designaban a las personas que eran demasiado escrupulosas o persistentes en sus rituales y oraciones con la esperanza de lograr de ese modo sus objetivos. Comenzó su obra La naturaleza con una dedicatoria a Venus y, tras argumentar que los dioses no se ocupaban de los seres humanos, atacó a la religión y la superstición como prácticas vanas. ${ }^{14}$ En este pasaje es evidente que Lucrecio no consideraba "religión" a las creencias en los dioses (que él mismo profesaba), sino a las prácticas rituales encaminadas a obtener el favor de los dioses, que no solo calificaba de vanas e inútiles —dado que los dioses no se conmovían ante tales ritos- sino también criminales - porque en ocasiones provocaban la muerte de personas-e incluso irreverentes, porque en el fondo eran prácticas que a los dioses ofendían. La religión según Lucrecio se nutría del miedo, como la superstición, y el objetivo de su obra sobre la naturaleza consistía precisamente en desatar los nudos de la religión que atenazaban a la mente. ${ }^{15}$

12 Cf. Nigidio Fígulo, citado por Aulo Gelio, Noctes Atticae, 4.9.1.

13 Cf. Servio, In Vergilii Aeneidem Commentarii, 2.1.226: "Secundum Lucretium superstitio est superstantium rerum id est caelestium et divinarum quae super nos stant, inonis et superfluus timor".

14 LuCRECIO, De Rerum Natura, 1.63-109:"Cuando en todo el mundo la vida humana permanecía ante nuestros ojos deshonrosamente postrada y aplastada bajo el peso de la religión, que desde las regiones del cielo mostraba su cabeza amenazando desde lo alto a los mortales con su visión espantosa, por primera vez un griego se atrevió a levantar de frente sus ojos mortales y fue el primero en hacerle frente" y — tras esta referencia a Epicuro- añadió que la"religión provoca acciones criminales e irreverentes (...) ya que si los hombres le vieran un final preciso a sus penalidades, podrían con algún fundamento oponerse a las supersticiones y amenazas de los adivinos". Traducción de Francisco Socas, Madrid, Gredos, 2003. También los capítulos 1.932; 4.7; 5.82-88; 6.58-64.

15 Cf. LucreCiO, De Rerum Natura, 1.932; 2.44; 3.54; 4.7; 5.1161-1240; 6.62. 
Sin embargo, tanto el término religente propuesto por Nigidio Fígulo como el concepto hipercrítico que Lucrecio tenía de la religio cayeron en desuso, imponiéndose en su lugar el giro que Cicerón (106-43 a.C.) — contemporáneo de ambos - dio a la palabra en Sobre la naturaleza de los dioses. ${ }^{16}$ Se trata de una interpretación claramente manipulada en la que el gran escritor latino obviaba la diferencia entre los adjetivos con sufijo de participio agente y los que incluían sufijo en -osus, con el objetivo de acuñar un nuevo significante para ambas palabras, basado en la oposición que en la filosofía griega se

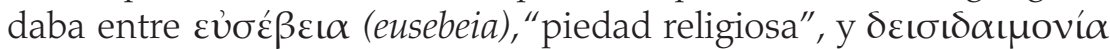
(deisidaimonia), traducido generalmente por "superstición", que se analizará después. De ahí que se inventase, a partir de un juego etimológico, que los antepasados de los romanos habían tenido la misma idea que los filósofos griegos. El discurso que Cicerón ponía en boca de Balbo era de claro carácter estoico y, por tanto, contrario al de epicúreos como Lucrecio. Jugaba con la raíz de superstitio para vincularla con los "cuentos de viejas" (superstes, "superviviente", se usaba también para designar a una persona anciana) y con el deseo de salvar a los hijos de enfermedades y catástrofes. Ese miedo a los

16 Cicerón, De Natura Deorum, 2.28.70-72: “¿Veis cómo a partir de unos hechos científicos descubiertos de una manera correcta y provechosa, nuestra razón se ha desviado hacia unos dioses imaginarios y ficticios? Esta circunstancia engendró creencias falsas, confusa desorientación y una superstición propia casi de ancianas. Y es que conocemos la forma de los dioses, su edad, su vestimenta y su adorno, además de sus linajes, sus bodas y sus parentescos, y en todo ello se ha establecido parangón con la debilidad humana, pues también se nos presentan con el espíritu perturbado. (...) No obstante, aunque se desprecien y se repudien cuentos como estos, (...) estos son los dioses a los que debemos venerar y rendir culto. Por lo demás, el mejor culto a los dioses —así como el más casto, devoto y lleno de piedad- consiste en venerarlos con mente y con voz siempre puras, íntegras e irreprochables. Y es que no solo los filósofos, sino también nuestros mayores, separaron la superstición de la religión. Pues quienes durante días enteros hacían preces e inmolaciones para que sus hijos supervivieran, fueron llamados supersticiosos, una denominación que se extendió después mucho más. Por otra parte, a quienes volvían a tratar con diligencia y — por así decirlo- «releían» todo lo referente al culto a los dioses, se les llamó «religiosos», de «releer» (como «elegantes» de «elegir», «diligentes» de «mostrar diligencia»e «inteligentes» de «mostrar inteligencia», porque en todas estas palabras se alberga el mismo sentido de «recoger» que se halla presente en «religioso»). Así es como, en el caso de «supersticioso» y de «religioso», se llegó a la denominación de un vicio por un lado, y a la de un elogio por el otro". Traducción de Ángel Escobar en Barcelona, Gredos - RBA, 2003. 
males de la naturaleza estaba claramente enunciado en el concepto griego de deisidaimonia, literalmente "miedo a los démones". Nótese que Cicerón relacionaba prácticas rituales con creencias, pero consideraba que estas podían ser diferentes en un mismo pueblo (las viejas y los plebeyos creen los cuentos mitológicos, pero los nobles ilustrados con formación filosófica no), sin que por ello se produjera un cambio de religio, concepto que definía claramente más adelante en un discurso que ponía en boca del pontífice Cota, ${ }^{17}$ como "los sacra y auspicios" del Estado romano. Sin embargo, en su Discurso contra Verres, Cicerón situaba religiones junto a auspicia, por lo que identificaba dicha palabra tan solo con los sacra o ritos sagrados instituidos por Numa y no con los auspicios instituidos por Rómulo. Tendía así a separar religio de cualquier práctica de tipo adivinatorio o profético. Repárese en que ya en el discurso de Cota había puesto en entredicho los augurios de los arúspices y las Sibilas.

Esta última es la definición que manejó Tito Livio (59 a.C. - 17 d.C.), que atribuyó a Numa la creación de las religiones, es decir, de los ritos sagrados romanos..$^{18} \mathrm{Al}$ inicio de la Era cristiana, en definitiva, ya se había impuesto la interpretación ciceroniana y se consideraba religio a todo culto legitimado por la legislación romana mientras que

17 Cicerón, De Natura Deorum 3.2.1-5:"Yo tenía que defender las creencias que hemos recibido de nuestros mayores acerca de los dioses inmortales, así como los sacra, las ceremonias y las religiones. Son cosas que yo, en realidad, he defendido siempre y que siempre defenderé y que nunca podrá apartarme el discurso de persona alguna - ya sea docta o no lo sea-de aquellas creencias que recibí de nuestros mayores acerca del culto a los dioses inmortales. Tratándose de religio sigo más bien a los pontífices máximos Tiberio Coruncanio, Publio Escipión y Publio Escévola, y no a Zenón, a Cleantes o a Crisipo. También cuento con Gayo Lalio, augur a la vez que sabio; prefiero oírle hablar de religio a él, en aquel célebre discurso suyo, que a cualquier jefe de los estoicos. Dado que toda la religio del pueblo romano se divide en sacra y en auspicios (a los que habría de añadirse una tercera cosa, si es que los intérpretes de la Sibila o los arúspices han sido capaces de suministrarnos - a partir de portentos y señales - alguna advertencia premonitoria), jamás pensé yo que hubiera de despreciarse ninguna de tales religiones. Así estoy persuadido de que Rómulo, mediante el establecimiento de los auspicios, y Numa, mediante el de los sacra, fueron quienes pusieron los fundamentos de nuestra ciudad, la cual no habría podido llegar nunca, ciertamente, a ser tan grande, si no hubiera aplacado de una manera excelsa a los dioses inmortales". He modificado la traducción de Ángel Escobar manteniendo en latín las palabras puestas en cursiva.

18 Cf. Cicerón, Contra Verres, 2.5.34; Tito Livio, Ab Urbe condita, 1.32.5. 
aquel otro que no había obtenido el beneplacitum de los legisladores recibía la calificación de superstitio. El gramático Festo (siglo II d.C.) distinguía el homo religiosus del homo superstitiosus basándose en que el primero daba culto a los dioses de su patria y el segundo a los extranjeros. ${ }^{19}$ Como dijo Maurice Sachot, se había pasado de"escrúpulo" a "religión civil" ${ }^{20}$ Cualquier culto bárbaro era, en consecuencia, designado como superstitio o religio illicita, incluso malefica.

El cristianismo a finales del siglo I y principios del II era calificado por Plinio el Joven, Tácito y Suetonio como superstitio, dado que era un culto extranjero que no había obtenido el permiso legal para celebrarse en las ciudades romanas. Pero antes de profundizar en la evolución del concepto de religio entre los cristianos de lengua latina hasta san Jerónimo, es necesario comentar, aunque sea brevemente, el ya mencionado debate producido en el mundo griego sobre la deisidaimonia, palabra esta última generalmente traducida por superstitio pero que en realidad tiene otro origen y una particular evolución.

\section{EL DEBATE FILOSÓFICO GRIEGO RESPECTO A EUSEBEIA, THRESKEIA Y DEISIDAIMONIA}

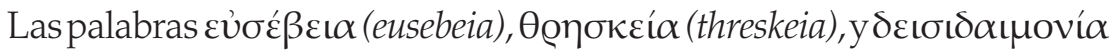
(deisidaimonia) se han utilizado en griego para referirse positivamente a la religiosidad, sin embargo, las dos últimas también han sido utilizadas como sinónimos de "superstición". Hay que detectar matices diacrónicos y sincrónicos. Así, por ejemplo, en la Atenas clásica el culto político (de la polis) se calificaba como eusebeia, que literalmente significa"buen culto", mientras que el término threskeia tenía el sentido de superstitio. Pero no fue este el sentido que tuvo en el resto del mundo helenístico.

Benveniste relacionaba la palabra threskeia con el verbo euthreîn, "guardar", "observar", "cumplir"y con el antónimo homérico atherizo, "descuidado". ${ }^{21}$ Como han resaltado Barton y Boyarin, threskeia se encuentra ya con el significado de "tabú" en Heródoto, Eurípides y Estrabón, pero con un sentido muy diferente en la epigrafía de Tracia

\footnotetext{
19 Cf. Luciano Pérez Vilatela, “La superstición según Plutarco: del bárbaro a Santo Tomás", Real Academia de Cultura Valenciana 9 (2009) 503-522 (506).

20 Cf. Maurice $\mathrm{S}_{\mathrm{ACHOT}}$, "Origine et trajectoire d'un mot: religion", Revue de philosophie ancienne XXI/2 (2003) 3-32 (7-12).

21 Cf. Benveniste, Vocabulario, 398.
} 
y Asia Menor. ${ }^{22}$ Heródoto (484-425 a.C.) lo aplicaba tan solo a cultos foráneos. ${ }^{23} \mathrm{El}$ mismo matiz de culto foráneo se apreciaba en Eurípides (484-480 a.C.), que atribuía a Orfeo la introducción en Grecia de los misterios de los tracios y por ello - decía- a la religiosidad de los misterios se le llamaba threskeia, del thrakos Orfeo.. ${ }^{24}$ La vinculación con los cultos mistéricos se aprecia también en Estrabón (63 a.C. - 23 d.C.) que relacionaba en Geografía (10.3.23) threskeia con"entusiasmo, artes adivinatorias, charlatanes y magos", y con los cultos dionisíacos y órficos. Sin embargo, frente a este significado de threskeia propio del dialecto ático, en la epigrafía de Tracia, Bitinia y la costa griega de Anatolia se detecta un significado positivo de la palabra, que significaría algo así como "nuestro culto". Es muy probable, por tanto, que la raíz tenga un origen tracio de carácter positivo - como dijo Eurípides-, y que adquiriese en el Ática un matiz despectivo para designar los cultos mistéricos foráneos y las costumbres adivinatorias, de la misma forma que la palabra "magia" designaba en principio al sacerdocio persa zoroástrico y pasó en griego a designar prácticas de hechicería.

En cuanto a deisidaimonia, literalmente significa "temor a los démones". La creencia en los démones tenía raíces remotas, probablemente indoeuropeas (que la vincularían con el culto latino a los di-manes, y con el culto iranio a los daeva-manya). Como tal, el culto a los démones no sería público, sino privado. Sin embargo, en el siglo VIII a.C., ya había confusión respecto al concepto de demon, puesto que, si para Hesíodo los démones benignos eran los espíritus de los difuntos de la Edad de Oro, para Homero los términos "démones"

22 Cf. BARTON - Boyarin, Imagine No Religion, 123-134.

23 Heródoto, Historia, 2.18.2; 2.37.3; 2.64-90:"considerándose a sí mismos libios y

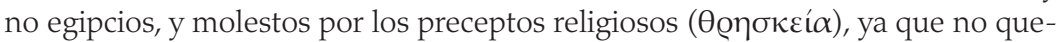
rían privarse de la carne de vaca, despacharon emisarios a Amón diciendo que entre ellos y los egipcios no había nada en común", añadiendo después que los sacerdotes egipcios siguen tabúes como la circuncisión, el afeitado completo del cuerpo, vestimenta de lino y sandalias de papiro, dos lavados diarios y dos noc-

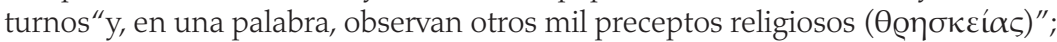

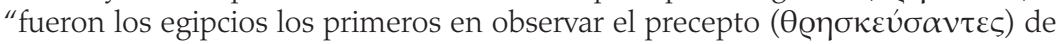
no yacer con mujeres en los santuarios (...)", "observan estrictamente todos sus

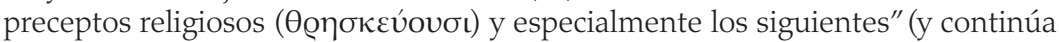
hablando de tabúes sobre animales, ritos de la vida cotidiana, adivinación, ritos funerarios, etc.). Traducción de Carlos SCHRADER, Madrid, Gredos, 2000. 
y "dioses" eran intercambiables, como ya apreciara Plutarco. ${ }^{25}$ En cualquier caso, todo apunta a que en los tiempos más antiguos no se concebía a los démones como algo negativo. La palabra eudaimonia significa "felicidad". Un eudemon es lo mismo que un makarios, es decir, un "bienaventurado" o"bien guiado", ya que tiene un "buen demon". Con Sócrates (470-399 a.C.) las creencias en los démones adquirieron mayor relevancia, porque el filósofo fue condenado a muerte por otorgar mayor credibilidad a su demon particular que a los dioses olímpicos. En cualquier caso, no consta que Sócrates desarrollara ningún tipo de "temor a los démones" ni practicara ritos mágicos para evitar los males que producía estar endemoniado, sino más bien todo lo contrario: el demon de Sócrates era una especie de ángel de la guarda. Por otra parte, no fue el único personaje histórico relevante que fuera guiado por un demon de la guarda, también eran famosos los casos de Lisis y Epaminondas. ${ }^{26}$

Probablemente, la deisidaimonia o"temor a los démones malvados" que poseían a los seres humanos y les producían enfermedades se introdujeran en el mundo griego por influencia asiática. En Fenicia, Siria, Palestina y Mesopotamia los rephaim o espíritus de los muertos se introducían en los cuerpos de los vivos produciéndoles enfermedades si no eran neutralizados mediante determinados rituales que los griegos calificarían de mágicos.

Los primeros en criticar las prácticas supersticiosas para curar a los enfermos fueron los médicos griegos. En uno de los pocos tratados del Corpus Hippocraticum unánimemente atribuido a Hipócrates de Cos (460-370 a.C.), Sobre la enfermedad sagrada, se criticaban las prácticas supersticiosas diciendo: "Por medio de discursos y prácticas de tal índole se jactan de saber más que nadie y engañan completamente a los hombres prescribiéndoles purificaciones y expiaciones; $\mathrm{y}$ la mayor parte de sus discursos versan sobre lo divino y demoníaco. $Y$ en verdad, a mí me parece que en sus discursos no revelan piedad, como creen, sino más bien impiedad, ya que implica que los dioses no existen. De hecho, su piedad y religiosidad es impiedad y sacrilegio, como voy a demostrar"27, y continúa explicando que los seres

25 Cf. Hesíodo, Los trabajos y los días, 122-124; Plutarco, Sobre la obsolescencia de los oráculos, 415B.

26 Cf. Plutarco, Sobre el demon de Sócrates, 586A.

27 Hirócrates, Sobre la enfermedad sagrada, 3. Traducción de J. AlsinA, “Hipócrates. Sobre la enfermedad sagrada", Boletín del Instituto de Estudios Helénicos 4/1 (1970) 87-96 (88). 
divinos no eran impuros, por lo que se les infamaba al concebir que transmitían impureza. No hay que olvidar que Hipócrates ejercía la medicina en el templo de Asclepio en Cos, por lo que considerar su epistemología como irreligiosa sería un anacronismo. Por el contrario, lo que los hipocráticos planteaban era más bien una teología alternativa en la que las divinidades clásicas eran simplemente las fuerzas de la naturaleza: sol, luna, vientos, frío, estrellas. ${ }^{28}$ En cualquier caso, no consta que las críticas de Hipócrates estuvieran relacionadas con la deisidaimonia, palabra que ni siquiera utiliza.

En cuanto a los filósofos, aunque Platón (427-347 a.C.) realizó una clara defensa de la legítima piedad de su maestro tanto hacia los dioses como hacia su demon y otorgó una gran relevancia al demon que acompañaba a cada individuo desde su nacimiento hasta su tránsito al Hades a través de la laguna Estigia, ${ }^{29}$ Jenofonte (430-354 a.C.) -otro de los discípulos de Sócrates, que se encontraba en Persia realizando la "Anábasis" cuando su maestro fue condenado a muerte- fue más ambiguo. Ciertamente defendió también en su Apología de Sócrates la compatibilidad entre la piedad cívica hacia los dioses y la comunicación individual con el demon, pero fue él quien utilizó — quizás por primera vez- el término deisidaimonia como sinónimo de "exceso ridículo de religiosidad" en su Agesilao, aunque se contradijo utilizando la misma palabra de forma positiva en la Ciropedia, tal como ha destacado Teodorsson..$^{30}$

Aristóteles (385-323 a.C.) decía que un tirano debe utilizar la deisidaimonia para atraerse al pueblo, "pero debe mostrarse en tal sentido sin parecer ridículo". ${ }^{31}$ Probablemente, ya aquí se aprecia un desprecio aristocrático hacia la deisidaimonia como un tipo de religiosidad plebeya, una idea en la que profundizó su discípulo y sucesor al frente del Liceo, Teofrasto de Lesbos (370-285 a.C.), que definió claramente el perfil del supersticioso (deisidaimon) en sus Caracteres (320 a.C.) como un individuo que desconoce cuál es el

28 Cf. Dale Martin, Inventing Superstition. From the Hippocratics to the Christians, Cambridge Mass., Harvard University Press, 2004, 36-50.

29 Cf. Platón, Fedón, 72b; República, 617c.

30 Cf. Jenofonte, Agesilao, 11.8; Ciropedia, 3.58. Sven Tage Teodorsson, " $\Delta \varepsilon \iota \sigma \iota \delta \alpha$ น 557-562.

31 Aristóteles, Política, 5.1315a. Traducción de Manuela García Valdés en Barcelona, Gredos - RBA, 2003. 
lugar apropiado para cada cosa, que abusa de los insultos y gritos, que carece de moderación y actúa de forma exagerada, que siente escrúpulos excesivos respecto a los demás y está obsesionado con el contagio que producen las cosas impuras, que muestra un miedo excesivo a los démones (características todas contrarias a las virtudes de los nobles y los filósofos: la valentía, la templanza, la moderación, la corrección, el"saber estar"); de ahí que el supersticioso recurriese a prácticas vulgares diferentes a las reguladas por la religiosidad de la polis, como consultar adivinos que no pertenecían a colegios sacerdotales de las polis y a intérpretes de sueños o de presagios avícolas que cobraban por sus vaticinios, como purificarse con agua cuando uno se cruzaba con un cadáver o una parturienta, como evitar a los locos y escupir al suelo al cruzárselos como sistema de protección, como usar amuletos y piedras con propiedades mágicas, etc. Una idea muy original de Teofrasto es la de considerar supersticiosa la práctica del sacrificio sangriento, planteando que antiguamente solo se ofrendaban vegetales a los dioses, que era el sacrificio que les placía de verdad ${ }^{32}$ (ciertos judíos esenios y los cristianos ebionitas desarrollarían una idea similar). Aristóteles admiraba tanto el sentido del humor de su discípulo — cuyo verdadero nombre era Tirtamo-, que lo apodó Teofrasto, y este hizo una descripción tan ridícula del supersticioso que ya nunca dejaría de formar parte del imaginario griego. Sin duda esta descripción -y no la cuestión del culto a los démones- era lo que conectaba el concepto griego de deisidaimonia con el latino de superstitio.

Sin embargo, a partir del ya mencionado Evémero de Mesina, que redujo a los dioses antiguos a la categoría de démones argumentando que eran espíritus de reyes de tiempos heroicos divinizados por sus súbditos, la confusión respecto al término aumentó, porque para muchos designaba ya no solo el temor a esos espíritus menores, los démones, sino a todos los dioses. De ahí que autores como Polibio (200-118 a.C.) o Diodoro Sículo (90-30 a.C.) en ocasiones utilizaran deisidaimonia como sinónimo de piedad y otras veces lo usaran como signo de exceso y, por tanto, de superstición. ${ }^{33}$ Posiblemente esto se explica también porque en época helenística se distinguía claramente entre los benefactores agathodémones o démones del amor

\footnotetext{
32 Cf. MARTIN, Inventing Superstition, 21-32.

33 Cf. Polibio, 6.56.7 y 9.19.1; Diodoro Sículo, 1.70.8 y 12.59.1.
} 
y los kakodémones o démones viciosos. Estos últimos eran los que producían enfermedades y hacían necesarios los milagros para exorcizar a los endemoniados. Pero también había quien utilizaba la magia negra para endemoniar a los enemigos. El temor a los démones llevó a masas de población del mundo helenístico a someterse a adivinos y magos que presumían de un poder especial frente a ellos, así como a utilizar amuletos y fórmulas rituales tanto orales como escritas para ahuyentarlos. La arqueología ha rescatado múltiples pruebas de su éxito. La filosofía epicúrea y estoica criticó este tipo de religiosidad popular basada en el miedo defendiendo el carácter científico de la medicina. Al mismo tiempo fue surgiendo una espiritualidad alternativa de tipo racionalista en la que el monoteísmo filosófico se imponía tras la superación del debate sobre el Uno entre Parménides y Heráclito a partir de Platón gracias a su teoría de las hipóstasis o emanaciones del Uno que hacían posible lo uno y lo múltiple, así como estableciendo un nuevo dios ordenador del universo a quien se atribuía la lógica de la naturaleza: el Logos, una entidad que cobró especial importancia en el estoicismo y el platonismo medio.

La situación cambió bajo la dominación del Imperio Romano. Plutarco de Queronea (46-127 d.C.), filósofo y sacerdote del Apolo de Delfos que desempeñó altos cargos bajo el gobierno de Trajano, escribió Sobre la deisidaimonia, probablemente inspirado en la obra perdida del cínico Bion de Borístenes (325-246 a.C.). ${ }^{34}$ Incluía en él como típicas prácticas "mancharse de lodo, revolcarse por el fango, festejar el sábado, echar sobre la tierra el rostro, sentarse torpemente delante de los dioses y postraciones inauditas", así como "las acciones y emociones ridículas de la superstición, sus encantamientos y magias, sus vueltas en círculo y sus toques de tambor, sus purificaciones impuras y sus sucios deberes religiosos, sus bárbaros y extravagantes castigos y ultrajes delante de los templos", llevar amuletos, así como los sacrificios humanos de gálatas, escitas y cartagineses, concluyendo al final que "algunos, al huir de la superstición, van a caer en un ateísmo cruel y obstinado, saltando por encima de la piedad (eusebeia) que se encuentra situada en medio". ${ }^{35}$ Su concepto de "superstición" tenía ya poco que ver con los kakodémones, y se hacía

34 Concepción Morales - José García, "Introducción", en Plutarco, Obras morales y de costumbres (Moralia), vol. II, Madrid, Gredos, 1986, 287-288.

35 Plutarco, Sobre la superstición, 166A; 171A-C; 171E. Traducción de Concepción Morales - José García en Madrid, Gredos, 1986. 
extensible al temor a los dioses en general, porque popularmente eran tanto los démones como los dioses los que provocaban enfermedades, epidemias o catástrofes naturales y había que neutralizarlos a todos ellos. El objetivo de Plutarco consistía, al igual que el de los médicos hipocráticos, en reformar la religiosidad politeísta eliminando la creencia en dioses imperfectos que provocaban el mal a los seres humanos, un objetivo demasiado utópico, dada la extensión de los mitos y creencias al respecto (Homero, sin ir más lejos). Eso no significa que asimilase démones y dioses como Evémero de Mesina. Plutarco utilizó el evemerismo para calificar de démones a algunos dioses como Isis y Osiris, pero no a otros como Apolo o Zeus. ${ }^{36}$ Aunque en Sobre el demon de Sócrates pusiese en boca del socrático Simmias el mito de Timarco de Queronea (identificación del demon como aquella parte del alma conocida como nous o conocimiento, idea que se inspira en realidad en Aristóteles, como ha explicado Teodorsson) y en boca del pitagórico Teánor de Crotona otra opinión más popular (los démones de las personas virtuosas se dedican a ayudar a los vivos ${ }^{37}$, Plutarco definía siempre estas opiniones como míticas, no como filosóficas, porque la verdad absoluta respecto a cuestiones metafísicas como los démones no se podía alcanzar. En esto seguía a Platón, que al hablar de los démones también utilizó la palabra mito, en el sentido de simples aproximaciones alegóricas a una verdad que por pertenecer a un mundo inmaterial no era del todo accesible a los humanos, como él mismo declara en Sobre Isis y Osiris: "A

36 Plutarco, Sobre Isis y Osiris, 360D. Respecto a la demonología de Plutarco, cf. Jaime Alvar, "Isis y Osiris daímones (Plut., De Iside, 360 D)", Arys 1 (1992) 245-263; Emilio Ángel García, "La idea de daimon en Plutarco", en Manuela García Valdés (ed.), Estudios sobre Plutarco: ideas religiosas. Actas del III Simposio Internacional sobre Plutarco. Oviedo 30 de abril a 2 de mayo de 1992, Madrid, Ed. Clásicas, 1994, 131-136. Respecto al conocimiento de Evémero por parte de Plutarco, fue indirecto, a través de Cicerón, de ahí que lo calificase de ateo, cuando no lo era, como ha explicado Vicente Domínguez, "¿Plutarco responsable del ateísmo de Evémero de Mesene? Comentario a De Iside et Osiride 360 A-B", en Manuela García Valdés (ed.), Estudios sobre Plutarco, 509-514.

37 Cf. Plutarco, Sobre el demon de Sócrates, 590B-594A (aunque más concretamente 591E y 593D-594A). La división del alma en psyche y nous, y el carácter inmortal y eterno del intelecto agente, aparecen en ARISTÓTELES, Acerca del alma, 429a-430a; Ética Nicomáquea, 1.1102a-b. Sven Tage Teodorsson, "The Psychology of De facie and De virtue morali", en Manuela García Valdés (ed.), Estudios sobre Plutarco, 115-122. 
las almas humanas aquí abajo, aprisionadas por los cuerpos y las pasiones, no les está permitido participar del dios, excepto en la medida en que es posible acceder con la inteligencia a una oscura visión a través de la filosofía" ${ }^{38}$ Como demostró Manuel Cerezo, las Vidas paralelas siguen la misma doctrina sobre la deisidaimonia que el tratado monográfico al respecto. ${ }^{39}$ Lo que Plutarco rechazaba era, por una parte, el culto a los démones y, por otra, aquellos ritos dedicados a alejar la maldad de los dioses, porque para él estos eran seres divinos en los que no cabía la maldad, sino todo lo contrario. ${ }^{40}$ Los dioses podían ser benefactores, por ello, el único culto adecuado era aquel destinado a obtener el favor de los dioses, es decir, el conjunto de sacrificios, procesiones y fiestas dedicados tradicionalmente por las polis a cada dios en su templo. Tampoco era superstición tener fe en los oráculos de los dioses. El culto a los démones era superstición no solo porque se basaba en el miedo y era un culto plebeyo caracterizado en general por su exceso y ridiculez y en ocasiones incluso por barbaridades como el sacrificio humano, ${ }^{41}$ sino también porque no era un rito cívico instituido por la tradición en las polis. Puesto que los dioses eran muy superiores a los démones, rindiendo un culto adecuado a los dioses no había por qué temer a los démones. La eusebeia era para Plutarco el culto a los dioses establecido por la polis. Dicho en latín: la religio de la polis. Aunque esta idea ya estaba presente en el pensamiento griego desde la condena de Sócrates en el siglo V a.C., se produjo un refuerzo de la misma por la influencia cultural romana (dentro del proceso intercultural que caracterizó la relación entre Roma y Grecia). En este sentido, el gran intelectual y político griego de

38 Plutarco, Sobre Isis y Osiris, 383F. Traducción de Francisca Pordomingo, Madrid, Gredos, 1995.

39 Cf. Manuel Cerezo, "La superstición según Plutarco de Queronea, ¿otra forma de religión?", en Manuela García VAldés (ed.), Estudios sobre Plutarco, 157-168. TEODORSSON, " $\Delta \varepsilon \iota \sigma t \delta \alpha u$ oví $\alpha$ ", 559-562, parece desconocer esta contribución del III Simposio Internacional sobre Plutarco en el que él mismo participó. Sirva como ejemplo — entre los múltiples citados por Cerezo - el de la Vida de Alejandro, 75.1-2, en que se concluye claramente que, si el ateísmo es malo, peor es la superstición.

40 Cf. Plutarco, Sobre la obsolescencia de los oráculos, 415A-417B. Cf. Martin, Inventing Superstition, 98-107.

41 Cf. Plutarco, Sobre la obsolescencia de los oráculos, 417C-E. 
la época de Trajano y Adriano sí que vinculaba los conceptos de eusebeia y deisidaimonia con los de religio y superstitio, uniendo así el pensamiento griego y el romano, como había pretendido unir la Historia de Grecia y Roma con sus Vidas paralelas. Nótese que conocía Sobre la naturaleza de los dioses de Cicerón, a quien dedicó una biografía. Sin embargo, al mismo tiempo estaba provocando un crac en el sistema filosófico, como ha defendido Dale Martin, ${ }^{42}$ por negar rotundamente el culto a los démones, aun admitiendo su existencia. ${ }^{43}$ Por otra parte, estaba proporcionando a aquellos que estaban en contra del culto a los dioses un argumento magnífico: uniendo evemerismo y anti-deisidaimonia podía combatirse todo el sistema religioso politeísta. Pero no serían ni los filósofos epicúreos ni los escépticos los que aprovecharían esta posibilidad lógica, sino los cristianos.

\section{EL USO CRISTIANO DE THRESKEIA Y DEISIDAIMONIA, Y EL CAMBIO CONCEPTUAL RESPECTO A RELIGIO}

El cristianismo tenía desde su origen una visión negativa de los démones que derivaba del pensamiento judío de época helenística, como puede apreciarse en textos como Tobías o Henoc. Los agathodémones desaparecieron, sustituidos por los ángeles, y solo quedaron démones malvados, causantes de las enfermedades, a los que el propio Jesús combatía. En este sentido, calificar al cristianismo de deisidaimonia carecía de sentido, porque los cristianos se manifestaban una y otra vez como enemigos de los démones. En el mundo latino, sin embargo, el uso de superstitio para definir al cristianismo, como ya se ha dicho, era común y tenía su lógica jurídica. Pero una verdadera revolución conceptual iba a producirse en cuanto los cristianos comenzasen a expresarse en latín.

Según Maurice Sachot, hasta el año 197 d.C. el cristianismo no se había definido a sí mismo como una religión sino como una filosofía, o más concretamente, como "la única filosofía segura y provechosa" tal como dice literalmente Justino Mártir (100-165 d.C.) en su Diálogo

42 Cf. MarTin, Inventing superstition, 93-108.

43 Plutarco prácticamente abandona la doctrina platónica del demon-guía, puesta en boca del pitagórico Teánor de Crotona, como hemos visto, pero no compartida por él, como ha defendido Santiago González, "EY $\triangle$ AIMONIA divina en el Colotes de Plutarco", en Manuela García Valdés (ed.), Estudios sobre Plutarco, 123-130. 
con Trifón (8.1) y solo a partir de Tertuliano se consideraría como una religio. ${ }^{44}$

Es posible. Pero también lo es - y desde mi punto de vista con mayor probabilidad - que Tertuliano no hubiera hecho más que seguir el uso de religio y superstitio iniciado en las traducciones de la Vetus Latina, que habrían comenzado a circular, según los expertos en el siglo $\mathrm{II}_{,}{ }^{45}$ y que sería el conjunto de traducciones utilizadas en Occidente hasta la Vulgata de san Jerónimo, versión que comenzaría a expandirse en la Tardoantigüedad. ${ }^{46}$ Tenemos manuscritos más an-

44 Cf. SACHOt, "Origine et trajectoire d'un mot: religion”, 13-19.

45 Hay más de 400 códices que contienen pequeñas partes de la Vetus Latina, pero pocos que contengan la Biblia casi completa. Es más abundante en ellos el Nuevo Testamento que el Antiguo, y más comunes los Evangelios que el resto de textos del canon neotestamentario que se cerraría bastante después de las primeras traducciones. Lo que nosotros llamamos Vetus Latina, los Padres de la Iglesia lo denominaban Vulgata y solo a partir de los carolingios comenzó a dedicarse este término exclusivamente a la traducción de san Jerónimo. Hoy día se distinguen al menos tres grupos de Vetus Latina: la Ítala, la Africana y la Hispana. La teoría comúnmente aceptada explica su origen de forma múltiple, es decir, se trataría de traducciones diversas realizadas en diferentes espacios y tiempos. La Ítala habría surgido a mediados del siglo II como reacción contra Marción, que había llevado en esa época su canon paulino a Roma. La Africana también se desarrollaría a mediados del siglo II e incluso, en lo que se refiere al Antiguo Testamento, pudo nutrirse de traducciones judías anteriores al latín, de cuyo uso en esta región hay indicios. Cf. Pierre-Maurice Bogaert, "La Bible latine des origines au moyen âge. Aperçu historique, état des questions (Première partie)", Reoue théologique de Louvain 19/2 (1988) 137-182. La hipótesis de una versión Hispana la defendió Teófilo Ayuso, La Vetus Latina Hispana, Madrid, Ed. CSIC, 1953, véase especialmente pp. 145-182. Para estudiar las diferentes versiones latinas he utilizado Pierre SABATIER, Bibliorum sacrorum latinae versiones antiquae, seu Vetus Italica, París, R. Florentain Rhemensis Typographia, 1751; John WORDswORTH y Henry J. White, Nooum Testamentum Domini nostri Jesu Christi latine, Londres, 1913; Alberto Colunga - Laurencio Turrado, Biblia Sacra Vulgatam Clementinam, Madrid, BAC, 1994; así como el instrumento más actual, Vetus Latina Database (agradezco al profesor Álvaro Pereira Delgado de la Facultad de Teología San Isidoro de Sevilla que me facilitase el acceso a este recurso electrónico).

46 Nacido en Estridón (Dalmacia), durante su estancia en Roma entre 382 y 384 comenzó la traducción de una nueva versión de la Biblia en latín (comparando con el texto griego) por indicación del papa hispano Dámaso, realizando entonces solo los Evangelios y los Salmos. Tras establecer su residencia en Belén, donde fundó un monasterio en 386, se dedicó hasta el 408 a traducir libros del Antiguo Testamento a partir del canon y el lenguaje hebreos. Cf. Juan Bautista Valero, "Introducción general a la obra", en San Jerónimo. Obras completas, vol. I, Madrid, BAC, 1999, 74-80; BOGAERT, "La Bible latine des origines au moyen âge”, 140: "La 
tiguos de la Vetus Latina que de las obras de Tertuliano, por lo que no debe considerarse como argumento la datación de los manuscritos sino la redacción de los textos. ${ }^{47}$

Un primer texto que debe tenerse en cuenta es 2 Mac 6,11: "En verdad algunos que se reunían en las cuevas cercanas y que celebraban secretamente el día del sábado, cuando fue descubierto por Filipo, fueron quemados vivos porque tuvieron escrúpulo de defenderse por respeto a la religio y la observancia (del día sagrado)" ${ }^{48}$ El Filipo mencionado era amigo de la infancia de Antíoco IV a quien dejó gobernando Judea tras la profanación del Templo. La versión principal

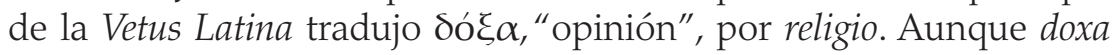
pudo haber sido usada aquí como modismo para aludir al templo de Jerusalén, también es posible que el escriba hubiese entendido el término como "conjunto de ideas o creencias", lo que supondría un claro vínculo de la religio con las creencias. Pero lo cierto es que religio podría entenderse en este pasaje de dos maneras: como el "tabú" y la santidad del sábado o como el"conjunto de creencias" respecto al sábado y la santidad del mismo.

Vulgate au sens moderne comporte les traductions de Jérôme sur l'hébreu (sauf pour le Psautier), sa traduction de Tobie et de Judith, sa révision des Évangiles et sa révision du Psautier sur l'édition hexaplaire d'Origène". La introducción de aquellos libros que san Jerónimo no tradujo en el corpus completo de la Biblia católica es un proceso largo y diverso que culmina en la edición de la Biblia Vulgata Clementina en 1592.

47 El manuscrito más antiguo en que se nos han conservado la mayor parte de las obras de Tertuliano es el Codex Agobardinus (s. IX), nº 1162 de la Biblioteca Nacional de París.

48 Alii vero, ad proximas coeuntes speluncas, et latenter sabbati diem celebrantes, cum indicati essent Philippo, flammis succensi sunt, eo quod verebantur propter religionem et observantiam manu sibimet auxilium ferre. Traducción propia. Este es el texto latino que pasó a la Vulgata, aunque no por traducción de san Jerónimo, que consideraba esta obra como no canónica. Es muy similar al texto griego:

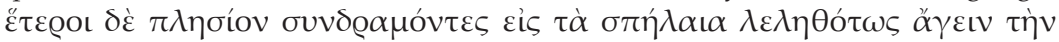

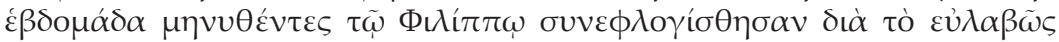

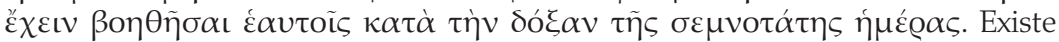
otra traducción en que desaparece la palabra religio, la de Lucifer de Cagliari, que citaba de una versión diferente de la Vetus Latina: Alii vero in proximas cucurrerunt speluncas, et latentes septimum diem celebrabant: quod cum indicatum esset, sufflammati sunt, eo quod metuerent in die solemni gloriosa ferre sibi auxilia. Como puede apreciarse, la palabra griega doxa se suprime en esta traducción. Cf. SABATIER, Bibliorum, v. II, 1088; José Manuel CAÑAs, Glosas latinas marginales de Vetus Latina en Biblias Vulgatas españolas. 1-2 Macabeos, Madrid, CSIC, 2000. 
Más común es el uso de la palabra religio en la Vetus Latina para traducir threskeia. Curiosamente, threskeia aparece solo en cinco libros bíblicos que no fueron traducidos por san Jerónimo, concretamente tres libros neotestamentarios (Hechos, Colosenses y Santiago) y dos veterotestamentarios de carácter deuterocanónico (Sabiduría - no incluido en el canon judío- y 4 Macabeos —-solo incorporado a la Biblia ortodoxa griega-).$^{49}$ Sabiduría se escribió probablemente en el siglo I a.C., es decir, en el contexto inmediatamente anterior a la redacción de los textos neotestamentarios, y 4 Macabeos en el I o II d.C., es decir, coetáneo a las redacciones neotestamentarias, por lo que constituyen un referente para comprender el uso y significado del término en las mismas. Obviamente, en el vocabulario griego de los traductores que a mediados del s. II a.C. realizaron la Septuaginta no existía o no se usaba threskeia.

En el libro de la Sabiduría, se criticaba en los capítulos 13 y 14 la idolatría, de ahí que, a modo de conclusión, en 14,18a se dijera:

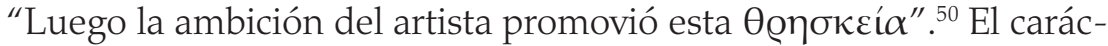
ter negativo de la palabra es aquí obvio, como "superstición". Este libro, según la mayoría de los expertos, fue escrito en Alejandría. El hecho de que también otros autores judeo-egipcios — como Filón de Alejandría o el escriba del Octavo Oráculo Sibilino - hayan usado el término de forma peyorativa indica una clara influencia en el griego alejandrino del griego ático. En Filón incluso se aprecia una oposición entre threskeia y eusebeia similar a la que Cicerón había planteado entre superstitio y religio.

Lo mismo cabe decir de 4 Macabeos, una obra que narra el martirio del anciano Eleazar y los siete hermanos Macabeos por parte del monarca seléucida Antíoco IV hacia el 168 a.C., cuyos cadáveres fueron trasladados a Antioquía, donde fueron venerados y se celebró la fiesta de su martirio tanto por parte de judíos como de cristianos, hasta que al principio del Medioevo las tumbas fueron trasladadas a Roma. El versículo que nos interesa es una frase en la que Antíoco dice:"Mira, anciano: antes de aplicarte ningún tormento, te aconsejo

49 Cf. John Friedrich Schleussner, Novum Lexicon Graeco-Latinum in Novum Testamentum, Londres, Ed. Longman et soc., 1826, 183; para los dos deuterocanónicos me baso en las reflexiones al respecto de BARTON - BOYARIN, Imagine No Religion, 142-148.

50 El único texto latino incluido en Vetus Latina Database es el de la Vulgata posterior a san Jerónimo, que tradujo threskeia por cultura, es decir,"culto". 
que comas carne de cerdo y salves tu vida. En realidad, respeto tu edad y tus canas, aunque no me pareces filósofo, puesto que tanto tiempo has observado la $\theta$ @ø $\sigma \varepsilon \varepsilon i ́ \alpha$ de los judíos" ${ }^{51} \mathrm{Al}$ ser puesta la palabra en boca de Antíoco IV, tiene un claro matiz peyorativo: los tabúes o supersticiones de los judíos. En la respuesta de Eleazar no aparece la palabra threskeia, sino eusebeia $(5,38$ y 6,22$)$ y nomos, ley $(6,27)$. En conclusión, el autor de 4 Macabeos sigue la tradición ática al respecto.

Este mismo sentido de threskeia como superstición, incluso como sinónimo de deisidaimonia, es el que utiliza el autor de la carta a los Colosenses, considerada pseudoepigráfica por la mayoría de los exégetas y datada entre el 70 y el 100 d.C.:"Que ninguno os defraude de vuestro galardón, haciendo alarde de humildad y culto de los ángeles, entregado a sus visiones, vanamente hinchado por la mente de su carne" ${ }^{52}$ Bover traduce aquí como"culto"la palabra threskeia dado que en las múltiples variantes del texto latino no solo se usa religio, sino también superstitio y cultura. ${ }^{53} Y$ ciertamente aquí el aspecto cultual de la palabra es ineludible, pero también debe incorporarse el matiz peyorativo, con lo que - en mi humilde opinión - la traducción más correcta sería "culto supersticioso". El autor de la epístola se dirigía a un grupo de la ciudad frigia de Colosas que celebraba una serie de rituales para ganar el favor de los ángeles, denominados en Col 1,16"tronos", "dominaciones", "arcontes" y "potestades", terminología que reaparece posteriormente en textos gnósticos. En Col 2,8 criticaba que los que dirigían a este grupo cristiano lo hacía

51 Traducción de Mercedes López Salvá en Apócrifos del Antiguo Testamento, vol. III, Madrid, Ed. Cristiandad, 1982, 145 (manteniendo threskeia en griego, que López traduce por"la ley", siendo preferible de nuevo"superstición").

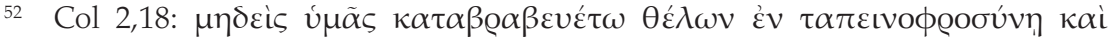

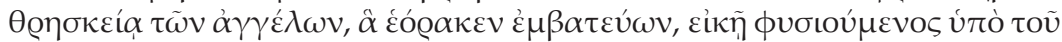

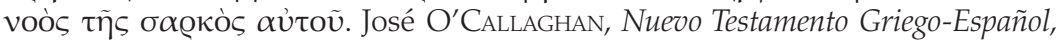
Madrid, BAC, 1997, 1119-1120. O'Callaghan usa la traducción de Bover, modificándola levemente, como dice en la introducción (p. XVI), que he utilizado como referencia para los textos neotestamentarios citados.

53 Wordsworth - White: Novum Testamentum, Londres, v. II, 511: "in Orig. (int. iii. 63) religione (-legione $\mathrm{BDG}^{*} \mathrm{NOPSZ}$, -ligionem L) angelorum (anguel. D, a ex

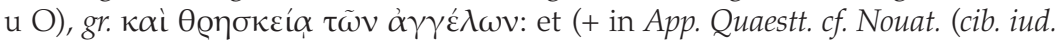
5) libere superstitionibus ang. servientes; et culturam ang. Aug. (ii. 514), et secta vel cultura ang. g. cf. Aug. Diserte ad Paulinum Nolensem addidit autem et culturam

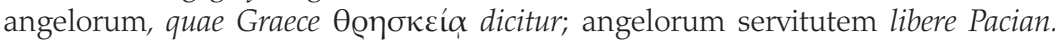
(bapt. 7)." 
"por medio de la filosofía y vana falacia". El autor de la carta, en de-

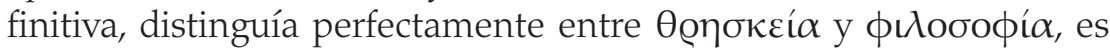
decir, entre las prácticas rituales y las creencias u opiniones. Desde su punto de vista, los herejes colosenses cometían errores de los dos tipos. Pero eso no los convertía en miembros de otra "religión", en el sentido moderno del término, porque no existía esa categoría conceptual. Todos eran cristianos, pero los colosenses estaban cayendo en prácticas supersticiosas de culto a los ángeles similares a las que realizaban por una parte los paganos con los démones y por otra los judíos, de ahí que se criticase también como threskeia los tabúes sabáticos y la circuncisión.

Es muy importante el cambio conceptual que se produce en la carta de Santiago respecto al sentido de threskeia: "Si alguno piensa ser hombre religioso (Өழךokós) no frenando su lengua, sino enga-

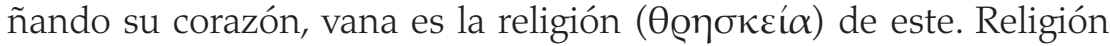

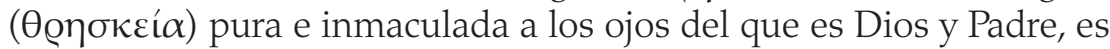
esta: asistir a los huérfanos y viudas en su tribulación, conservarse a sí mismo incontaminado del mundo" (Sant 1,26-27)..$^{54}$ Se trata de dos versículos que vienen a reforzar lo dicho en Sant 2,17-19: "Así tam-

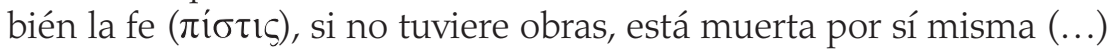

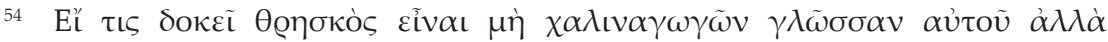

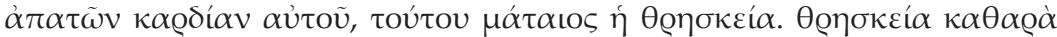

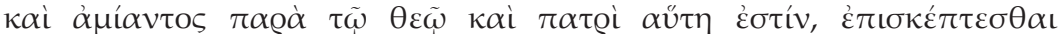

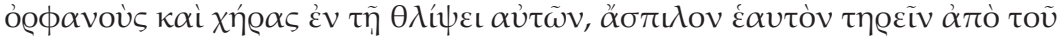
kóouov. O'Callaghan, Nuevo Testamento Griego-Español, 1290-1. Traducido al latín en el Codex Corbeiensi (manuscrito de la Vetus Latina Itala de los ss.VIII-X): Si quis autem putat se religiosum esse, non infraenans linguam suam, sed fallens cor suum, huius vana est religio. Religio autem munda, et immaculata apud Dominum, haec est: Visitare orphanos, et viduas in tribulaciones eorum, servare se sine macula a saeculo. Cf. SABATIER, Bibliorum, vol. III, 934. El uso de religiosum para traducir

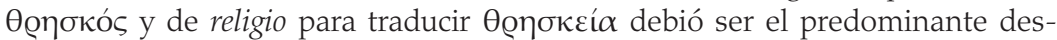
de el principio ya que, como se aprecia en Vetus Latina Database, aparece en la Vulgata posterior a san Jerónimo, en Pseudo Hilario de Arlés, In epistulas canonicas 62,305; en el Responsoriale Romanum, 6954, 239; y en los Concilios de Toledo $10.9,316$ y $11.1,355$. Sin embargo, hay otro uso, no constatado en esta base de

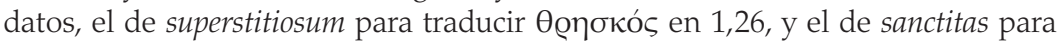

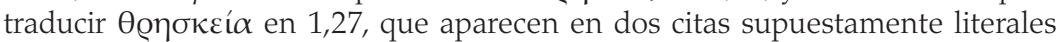
del Pseudo-Agustín, Liber de Divinis Scripturis sive Speculum, 51.524,8 y 24.411,5. Dicha obra se sitúa en la tradición de la Vetus Latina Hispana. Cf. Walter THIELE, Epistulae Catholicae, Friburgo, Ed. Herder, 1956, 21. Sin embargo, dado que el es-

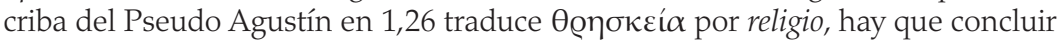
que no contradice el sentido de la traducción mayoritaria. 
¿Tú crees que Dios es uno? Haces muy bien, también los demonios ( $\delta \alpha \mu$ óvı $\alpha$ ) creen y se estremecen".$^{55}$ Este era el objetivo principal de la epístola: combatir la creencia de que solo con fe y sin necesidad de obras el cristiano podía salvarse. Aunque se ha considerado un mensaje antipaulino, no lo era realmente, ${ }^{56}$ porque lo que Pablo condenaba eran "las obras de la Torá", es decir, los mandatos y ritos de la Ley judía que no debían considerarse necesarios para los gentiles cristianizados (lo que tradicionalmente se concebía como la threskeia o religio), mientras que exaltaba la caridad. Y lo que Santiago ${ }^{57}$ decía era que había que practicar la caridad, el amor al prójimo, ejemplificado aquí en los huérfanos y las viudas, los que en la época tenían más dificultades para valerse económicamente por sí mismos. En definitiva, estaba diciendo lo mismo que Pablo: no os preocupéis tanto por los ritos (sentido antiguo de threskeia y religio) y haced el bien al prójimo, esa es la religión pura (nuevo sentido de threskeia y religio).

Se trata de un texto relevante no solo porque utilizó el término threskeia en el mismo sentido positivo en que lo usaron las fuentes epigráficas de Tracia, Bitinia y la costa griega de Anatolia, sino también porque el objetivo de Santiago consistía en otorgar un nuevo significado a la palabra que — al ser traducida por religio en la Vetus Latina - supuso un cambio semántico radical que afectaría al concepto en los siglos venideros, porque durante dos milenios se leerían

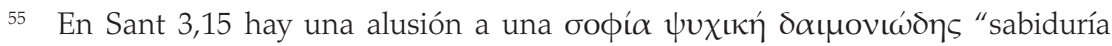
animal (literalmente, "psíquica») endemoniada", lo que demuestra que el autor consideraba a los démones como seres sobrenaturales atrapados en el mundo terrenal. Cf. O'Callaghan, Nuevo Testamento Griego-Español, 1294-9.

56 Hans-Josef KLAUCK, "Debate sobre la justificación: Pablo, Santiago y Martín Lutero", Carthaginensia. Revista de Estudios e Investigación 31 (2001) 67-86. Interesante estudio de conciliación entre Pablo y Santiago, aunque desde mi punto de vista hay que ir más allá, ya que Pablo simplemente cuestionaba la obligatoriedad de cumplimiento de los 613 mitzvot de la Torá por parte de los gentiles creyentes en Cristo (los judíos creyentes en Cristo - como el mismo Pablo dijo e hizo- debían cumplir los mitzoot).

57 El debate sobre el autor y la fecha de redacción de la carta divide prácticamente por la mitad a los que la consideran muy antigua y vinculada con el círculo de escribas al servicio de Santiago el Justo, el hermano de Jesús que dirigió la iglesia desde Jerusalén hasta el 62 o 64 d.C., y los que consideran que se trata de un texto de finales del siglo I o principios del II. Cf. Pedro Giménez de Aragón, “La Carta de Santiago y los orígenes del judeocristianismo", en Israel GaLLaRTe - Jesús Peláez, In Mari Via Tua. Philological Studies in Honor of Antonio Piñero, Córdoba, El Almendro, 2016, 597-615. 
estos textos en las iglesias de Europa occidental transmitiendo al pueblo que la verdadera religión no eran los rituales, sino las obras de amor al prójimo, el mandamiento primero de Jesús, es decir, la ética. De los tres elementos de la actual categoría conceptual "religión" —creencias, prácticas rituales y prácticas éticas-, Santiago valoraba el tercero por encima del segundo, que hasta el momento había ocupado un lugar prioritario, por no decir único, en dicha categoría.

También el autor de los Hechos de los Apóstoles utilizó threskeia en sentido positivo, como sinónimo de eusebeia y como antónimo de deisidaimonia, es decir, en línea con la epigrafía de Tracia, Asia y Bitinia, pero valorando más bien el aspecto ritual. Antes de abordar el modo en que dicho autor utilizó threskeia, creo necesario abordar el uso de deisidaimonia, dado que la definición de threskeia se hace en oposición a esta otra palabra, incorporando así en los textos sagrados cristianos el debate entre religión y superstición del mundo grecorromano. Deisidaimonia aparece dos veces: primero en Hch 17,22 (aquí como adjetivo comparativo) y después en Hch 25,19.58 Algunos han traducido —en mi opinión incorrectamente-—estos dos últimos casos como "religiosos" $\mathrm{y}$ "religión", por ejemplo, Teodorsson, que dice que el autor de Hechos utilizó la palabra en sentido positivo, al igual que José María Bover, que traduce Hch 17,22 de la siguiente manera: "De pie Pablo, en medio del Areópago, dijo: «Varones atenienses, en todas cosas os veo respetuosos, como nadie, de lo divino»" ${ }^{59}$ Para entender el verdadero sentido del término es conveniente analizar las versiones latinas, relacionar ambos pasajes con el léxico del escriba de Lucas-Hechos y compararlos con el discurso de Hch 26.

La palabra griega clave aquí es $\delta \varepsilon เ \sigma \iota \delta \alpha \mu$ เ la Vetus Latina Itala se tradujo unas veces por supertitiosos y otras por supertitiosiores..$^{60}$ Deisidaimonesterous es un comparativo que debería interpretarse como superlativo. Aunque en latín el discurso ante el

\footnotetext{
Cf. Schleusner, Lexikon, 92. Cf. TeOdorsson, " $\Delta \varepsilon \iota \sigma \iota \delta \alpha \iota \mu o v i ́ \alpha ", 558 ;$ O'Callaghan, Nuevo Testamento Griego-
Español, 734-5.
}

60 En Vetus Latina Database se aprecia que en más ocasiones se usa supertitiosos (cod. 5, 50 y 51) que supertitiosiores, interpretación gramaticalmente más correcta atendiendo al griego, ya que $\delta \varepsilon \iota \sigma \iota \alpha \iota \mu o v \varepsilon \sigma \tau \varepsilon \dot{c}$ ous es un comparativo de superioridad que debe considerarse como superlativo, una corrección probablemente introducida por san Agustín, Contra Cresconium grammaticum et donatistam 1,15. Los dos códices más antiguos de los Hechos de los Apóstoles de la Vetus Latina, ambos díglotas (griego y latín) son: Bezae Cantabrigiensis (s. V) y Laudianus (s. 
Areópago comenzara con un insulto, en griego cabe la ambigüedad. Este versículo se sitúa en el contexto de la predicación de Pablo en Atenas. Acababa de huir de Tesalónica y Berea perseguido por los líderes de sus sinagogas, a las que había acudido convirtiendo tanto a judíos como a gentiles temerosos y - especialmente - temerosas de Dios, y ahora enseñaba en la sinagoga de Atenas, en el ágora y, finalmente, en el Areópago, donde fue llevado bajo la acusación de predicar dioses foráneos, que era un delito en Atenas. Como explica Fitzmyer, este pasaje (Hch 17,16-34) es probablemente una invención del autor de los Hechos en el que se inserta un discurso con un vocabulario bastante ajeno a Pablo, muy helenístico. ${ }^{61}$ El Pablo de este discurso había mostrado su enorme disgusto justo antes por la gran cantidad de estatuas y templos de Atenas y, una vez en el Areópago, le dijo descaradamente a los senadores atenienses que se equivocaban al"pensar que lo divino sea algo semejante a oro o plata o piedra, escultura labrada por el arte y la fantasía de un hombre" (Hch 17.29), es decir, los trató como si fueran unos ignorantes. Por tanto, no debemos dudar de su intención crítica al calificarlos de deisidaimonesterous, porque esta palabra griega tenía doble sentido ("los más supersticiosos" o "los más religiosos"), como se ha visto anteriormente. El autor del texto introdujo precisamente esta palabra jugando con su ambigüedad, como ya destacó Johnson, entre otros. ${ }^{62}$ Desde el punto de vista cristiano, estaba insultando a los areopagitas, desde el punto de vista griego, los estaba alabando. Sería una contradicción que Pablo dijera que los atenienses eran "los más religiosos" en sentido positivo. Para mí, la traducción más correcta que conserva el doble sentido del original sería la literal:"los más temerosos de los démones".

No cabe pensar que el escriba desconociese el vínculo de deisidaimonia con los démones, ya que había usado la palabra daimon en múltiples ocasiones. ${ }^{63}$ El término no solo aparecía en Marcos y en

VI-VII) que procedían respectivamente de Lyon y Cerdeña y se encuentran ahora en Cambridge y Oxford, cf. SABATIER, Bibliorum, vol. III, 493-494.

61 Cf. Joseph Fitzmyer, Los Hechos de los Apóstoles, Salamanca, Sígueme, 2003, 266 291 (nótese al final la enorme bibliografía que ha generado este pasaje).

62 Cf. Luke Timothy Johnson, The Acts of the Apostles. Sacra Pagina 5. Collegeville, MN, The Liturgical Press, 1992.

63 En Hch 17,18, y también en Lc 4,41; 8,2.27.30.33.35.38; 9,1.49; 10,17; 11,15.18.19.20; 13,32. 
el documento Q, las fuentes principales del autor de Lucas-Hechos para la parte evangélica, sino que también había sido usado ya por Pablo, cuyas cartas probablemente también utilizó. Concretamente se encuentra en la Primera Carta a los Corintios: "Pero es que lo que inmolan los gentiles, a los demonios, y no a Dios, lo inmolan. Y no quiero que entréis en comunión con los demonios" ${ }^{64}$ Es el único lugar en que Pablo usa la palabra "demon", ya que 1 Tim 4,1 es pseudoepigráfica.$^{65}$ Como comenta Antonio Piñero, la palabra koinonia, "comunión", significa"participar de algo en común", una"unión intracomunitaria"; al comer el cuerpo de Cristo los cristianos formaban parte de dicho cuerpo, de modo que aquellos que comían la carne sacrificada a los dioses estaban en comunión con dichos dioses o démones, en la unión intracomunitaria del Imperio Romano. ${ }^{66}$ De ahí que Pablo defendiese después que, aunque todo es lícito al cristiano, no todo le convenía. El lema "todo es lícito" probablemente procedía del propio Pablo en su primera evangelización de los corintios, pero fue malinterpretado por los seguidores del líder cristiano Apolo, por lo que Pablo se vio obligado a corregirlo en esta carta. En cuanto al uso del término "démones", es un fragmento muy importante porque probablemente sea el texto cristiano más antiguo en que se devalúa a los dioses grecorromanos a la categoría de démones, lo que significa que quizás Pablo conocía la filosofía evemerista, aunque solo fuera superficialmente, y que fue el primer cristiano en utilizarla para combatir al politeísmo. Pablo creía que los ídolos no existían, pero los démones sí, y actuaban detrás de las caretas de los supuestos dioses (1 Cor 8,5). Muy posiblemente esta idea ya figuraba en el pensamiento judío de la época. Por cierto, ni Pablo ni los evangelistas usan la palabra threskeia para referirse a su Пíotıs o fe, de lo que se deduce que la threskeia o religio de Pablo y los evangelistas era la

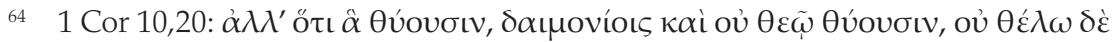

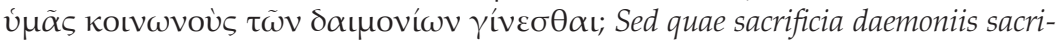
ficant (Sed quae immolant gentes, daemoniis immolant), et non Deo. Nolo (autem) vos daemoniorum socios fieri. Las versiones más antiguas de Vetus Latina Italica de las epístolas de Pablo se encuentran en los códices díglotas Claromontanus (ss.V-VI) y Sangemanensis (s. X). Cf. SABatier, Bibliorum, vol. III, 591-592; O'Callaghan, Nuevo Testamento Griego-Español, 938-9.

65 Cf. Antonio Piñero, Guía para entender el Nuevo Testamento, Madrid, Ed. Trotta, 2006, 443-459.

66 Cf. Antonio PIÑERo, Guía para entender a Pablo de Tarso. Una interpretación del pensamiento paulino, Madrid, Ed. Trotta, 2018, 293-296. 
misma que la del resto de los judíos, es decir, el culto en el Templo de Jerusalén y en la sinagoga. Eso no significa que Pablo confundiese a los judíos (el Israel según la carne de 1 Cor 10,18), con los cristianos (lo que después se denominaría el Verus Israel, compuesto de judíos cristianos y gentiles cristianos). Simplemente significa que la diferencia entre ambos grupos no era de religio, sino de fides. ${ }^{67}$

De hecho, al comparar Hch 17,22 con Hch 25,1-26,32, se confirma esta interpretación de la religio de los cristianos como una religio judía. Cuando el gobernador romano Festo llegó a Cesarea, se encontró que su predecesor Félix le había dejado a Pablo en la cárcel por la denuncia de las autoridades judías de Jerusalén. Como no sabía qué hacer con él, recurrió a Herodes Agripa II y Berenice para que intervinieran. En la explicación que el escriba de Hechos ponía en boca de Festo, este usaba la palabra deisidaimonia para definir las prácticas religiosas de Pablo y los demás judíos (Hch 25,19). Evidentemente, lo que el escriba quería mostrar era el desprecio del gobernador romano hacia las diferentes corrientes de religiosidad judía, que consideraba superstitiones, es decir, cultos bárbaros, no grecorromanos. Solo en el discurso de Pablo en presencia de Agripa II aparece la palabra threskeia (religio):

Me considero feliz, rey Agripa, al tener hoy que defenderme ante ti de todos los delitos de que soy acusado por los judíos, mayormente siendo tú conocedor de todo lo referente a los judíos, así usos como cuestiones; por lo cual te ruego me escuches pacientemente. Mi vida, pues, a partir de la juventud, cual la pasé desde el principio en mi nación y en Jerusalén, la saben todos los judíos; que ya de antes y muy atrás me conocen y saben,

67 La pistis se define básicamente como "fidelidad", "devoción", "el estado de adhesión intelectual y activa a alguien o algo"; cuando va unida a la divinidad adquiere el matiz de"confianza"y de"calidad de adhesión personal a la divinidad"; cuando aparece en relación con una acción previa adquiere el matiz de "fe" o "adhesión a alguien o algo como consecuencia de una acción previa"; y cuando va asociada a una acción comunicativa adquiere el significado de"creencia", "enseñanza" o"un grupo de doctrinas"; como ha demostrado, basándose en las car-

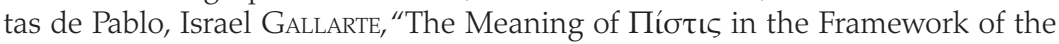
Diccionario griego-español del Nuevo Testamento", en Daniel L. AkIN - Thomas W. Hudgins, Getting into the Text. New Testament Essays in Honor of David Alan Black, Eugene, OR, Pickwick Publications, 2017, 179-189. 
si quieren dar testimonio, que conforme a la secta más estricta de nuestra religión viví como fariseo (Hch 26,2-5). ${ }^{68}$

Cuando Pablo decía "nuestra religión" se refería al culto judío a Yahvé, que compartían Agripa II y él. Lo que no compartían era

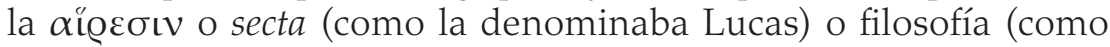
la denominaba Flavio Josefo), que en la juventud de Pablo era la farisea y en el momento en que hablaba ante Agripa II era la cristiana. Nótese que el Pablo de Hechos no usaba deisidaimonia como había hecho para referirse al culto de los atenienses o como había hecho Festo para referirse al culto de los judíos, sino threskeia. Evidentemente, el escriba consideraba más respetuosa esta palabra para referirse a la religio de los judíos y cristianos, el culto a Yahvé, el Dios único, que la palabra deisidaimonia utilizada para referirse en 17,22 al culto politeísta. No cabe duda de que el escriba conocía el debate entre los filósofos griegos anteriormente explicado sobre la deisidaimonia, pero en lugar de utilizar eusebeia como antónimo, usó threskeia y, por otra parte, aplicó los términos de dicho debate a la lucha de los cristianos por convertir al monoteísmo de Yahvé a los gentiles politeístas.

Por tanto, defiendo que no fue Tertuliano el primero en plantear la revolución conceptual que suponía considerar al cristianismo como la vera religio frente a los politeístas romanos que la calificaban de superstitio, e invertir los términos para calificar al politeísmo de superstitio. Tertuliano no hizo más que continuar la línea iniciada por los autores de la carta de Santiago y los Hechos de los Apóstoles, escritos un siglo antes ${ }^{69}$, quizás traducidos al latín antes de que él escribiese sus tratados.

Los cristianos de Roma habían asumido ya el sentido positivo de la palabra threskeia y su equivalencia con religio ya antes incluso de la

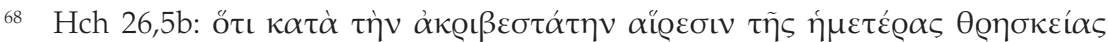

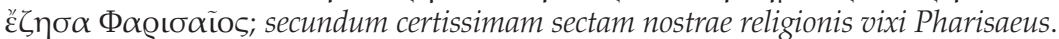
O'CaLlaghan, Nuevo Testamento Griego-Español, 786-787.

69 Ya mencioné el debate sobre la datación de Santiago en nota 56; en cuanto a la datación de Hechos, el debate es considerable. Frente a la versión tradicional que sitúa su fecha de redacción en torno al 80 d.C., la investigación reciente ha argumentado con fuerza en favor de una datación más tardía, entre el 100 y el 135 d.C. Destaco aquí Barbara Shellard, New Light on Luke. Its Purpose, Sources and Literary Context, Journal for the Study of the New Testament (Supplement Series 215), London - New York 2002, 31-34. 
difusión en la Urbe de los Hechos de los Apóstoles, como demuestra la primera carta de Clemente a los corintios escrita en torno al 96 d.C. Clemente era el secretario ab epistulis del consejo de presbíteros de la iglesia romana, ${ }^{70}$ que en su carta a la comunidad de Corinto definía como idéntico el culto celebrado por la iglesia romana y el culto judío de los mártires Ananías, Azarías y Misael del libro de Daniel (1 Clem 45,7 y 62,1; Dan 1,6ss.). Se daba, por tanto, la misma identificación entre culto judío y culto cristiano que se veía en Hch 26. Evidentemente, se admitía la similitud en las prácticas rituales y el objeto de culto (Yahvé, el único Dios), aunque no tuvieran exactamente las mismas creencias (algunos judíos no creían que Jesús fuera el Mesías).

Hay una clara explicación de por qué Hechos (y quizás también 1 Clemente) utilizó threskeia en el sentido positivo de la epigrafía de Tracia, Asia y Bitinia: porque conocía y era deudor de la obra de Flavio Josefo — como demostró Barbara Shellard, citada en nota 69-, el autor judío que más veces usó la palabra threskeia para hablar del culto judío, especialmente en Antigüedades Judaicas, una obra basada en la Biblia (un hecho destacable dada la ya mencionada ausencia de dicho término de la versión griega de los Setenta). Como han demostrado Boyarin y Barton, ${ }^{71}$ Josefo utilizó el término positivamente y

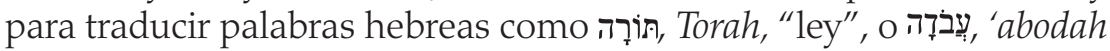
("oficio", "servicio", "obra", "trabajo"), que está claramente relacionada con بִבְדִָים 'abadim ("siervos"), por lo que es evidente que hacía alusión al servicio religioso. ${ }^{72}$ En los Setenta se traducía Torah por nomos (aunque la palabra hebrea incluía normas no solo de legislación administrativa, civil o penal como las promulgadas por los griegos, sino también de carácter moral y ritual), mientras que 'abodah se solía traducir por therapeia.

En el Discurso a Diogneto (mediados del siglo II) encontramos un desarrollo del debate entre deisidaimonia y threskeia o theosebeia ("culto a Dios"), pero con la introducción de un cambio

70 Cf. Tassilo Schмiт, Paroikie und Oikoumene. Sozial- und mentalitätsgeschichtliche Untersuchungen zum 1. Clemnensbrief, Berlin, Walter de Gruyter, 2002, 115-116.

71 Cf. BARTON - BOYARIN, Imagine No Religion, 155-177.

72 "Siervos" también se decía 'abudah según Jaime Vázquez Allegue, Diccionario bíblico, Pamplona, Verbo Divino, 2002, 162. 
sustancial respecto a los Hechos de los Apóstoles, las cartas de Pablo y 1 Clemente, puesto que aquí son los judíos los que practicaban la deisidaimonia:

Pues veo, excelentísimo Diogneto, tu extraordinario interés por conocer la theosebeia de los cristianos y que muy puntual y cuidadosamente has preguntado sobre ella: primero, qué Dios es ese en que confían y qué género de culto (threskeiontes) le tributan para que así desdeñen todos ellos el mundo y desprecien la muerte, sin que, por una parte, crean en los dioses que los griegos tienen por tales y, por otra, no observen tampoco la deisidaimonia de los judíos. ${ }^{73}$

El autor del Discurso a Diogneto conocía perfectamente el debate de los filósofos griegos sobre la deisidaimonia y lo aplicó al enfrentamiento entre cristianos y judíos. Sin duda, le interesaba captar la atención de un personaje noble para cambiar su percepción sobre el cristianismo como simple superstición judía (basada en Tácito, Plinio y Suetonio, entre otros que no nos han llegado). En este sentido es interesante la hipótesis que considera que el Discurso a Diogneto es en realidad la Apología del obispo Quadrato de Atenas al emperador Adriano. ${ }^{74}$ Independientemente de que la aceptemos o no, hay que resaltar que el autor no se atrevió a calificar de deisidaimonia la religiosidad de los griegos. La creencia en un único Dios es definida como la pistis o fe cristiana. Aunque no existía aún la categoría conceptual de "religión" como sistema de creencias y prácticas, sí es cierto que en este texto encontramos ya referencias claras al cristianismo como pistis (10.1), threskeia y theosebeia. Igualmente, los cristianos no son calificados como un pueblo ${ }^{75}$ sino como un nuevo tipo de personas que habita en ciudades griegas y bárbaras.

Probablemente Tertuliano (160-220 d.C.), el primer escritor cristiano en latín que nos ha llegado, conoció el debate existente en el cristianismo grecoparlante entre deisidaimonia y eusebeia/threskeial

73 Discurso a Diogneto, 1.1. Traducción de Daniel Ruzz BuEno en Madrid, BAC, 1993, 845. He modificado las palabras en cursiva manteniendo el original griego porque no creo adecuado traducir theosebeia por "religión". En el capítulo 3.1-3, vuelven a aparecer las palabras theosebeia y threskeia como sinónimos y con el significado claro de "culto". Y en 4.1 desarrolla lo que considera la deisidaimonia de los judíos: sábados, circuncisión, novilunios, calificándolas de ridículas.

74 Cf. Daniel Ruzz Bueno, "Introducción” al Discurso a Diogneto, 820-844.

75 Tal como hacían 1 Pedro, Bernabé y Arístides en su Apología. 
theosebeia. También es bastante probable que leyese en latín textos de la Vetus Latina Africana. En cualquier caso, leyese el Nuevo Testamento en griego o en latín, apreciaría allí el debate entre threskeia-religio y deisidaimonia-superstitio presente en Hch 17 y 25-26. Sin embargo, ni en Hechos ni en ningún otro texto neotestamentario se usa sustantivo alguno para designar al cristianismo. Tan solo se utiliza el adjetivo "cristiano", que podía simplemente designar (al igual que "fariseo" o "saduceo") a un tipo de judío. Tertuliano utilizó un sustantivo abstracto para designar al mundo cristiano: christianismus. ${ }^{76}$ Aunque fue Ignacio de Antioquía el primero en introducir en el 107 o 114 d.C. la palabra griega christianismós, lo cierto es que no lo hizo con el sentido que actualmente tiene, de sistema religioso, sino con otro muy diferente, propio de los sustantivos abstractos griegos terminados en -ismos, por lo que debería traducirse por" cristianización". ${ }^{77}$ Sin embargo, en los textos citados de Tertuliano se identificaba al cristianismo con el Evangelio mientras que al judaísmo se le identificaba con la Torá y los Profetas. No está claro si Tertuliano consideraba al christianismus como religio, entre otras cosas porque tampoco hay en Tertuliano una definición de religio más allá de "culto sagrado". En ningún sitio relacionaba esta palabra con ideas y creencias. Sí consideraba la religio

76 Tertuliano, Adversus Marcionem, 4.6.3: Sic habebit intentio et forma opusculi nostri, sub illa utique conditione quae ex utraque parte condicta sit. Constituit Marcion alium esse Christum qui Tiberianis temporibus a deo quondam ignoto revelatus sit in salutem omnium gentium, alium qui a deo creatore in restitutionem Iudaici status sit destinatus quandoque venturus. Inter hos magnam et omnem differentiam scindit, quantam inter iustum et bonum, quantam inter legem et evangelium, quantam inter Iudaismum et Christianismum; 4.33.8: Quasi non et nos limitein quendam agnoscamus Ioannem constitutum inter vetera et nova, ad quem desineret Iudaismus et a quo inciperet Christianismus, non tamen ut ab alia virtute facta sit sedatio legis et prophetarum, et initiatio evangelii in quo est dei regnum, Christus ipse. Nam et si probavimus et vetera transitura et nova successura praedicari a creatore, si et Ioannes antecursor et praeparator ostenditur viarum domini evangelium superducturi et regnum dei promulgaturi, et ex hoc iam quod Ioannes venit ipse erit Christus qui Ioannem erat subsecuturus ut antecursorem, et si desierunt vetera et coeperunt nova interstite Ioanne, non erit mirum quod ex dispositione est creatoris, ut undeunde magis probetur quam ex legis et prophetaram in Ioannem occasu et exinde ortu regnum dei; y 5.4.8: Propter quod, fratres, non sumus ancillae filii sed liberae, utique manifestavit et Christianismi generositatem in filio Abrahae ex libera nato allegoriae habere sacramentum, sicut et Iudaismi servitutem legalem in filio ancillae, atque ita eius dei esse utramque dispositionem apud quem invenimus utriusque dispositionis delineationem.

77 Cf. Pedro Giménez de Aragón, “Ignacio de Antioquía inventó el Cristianismo. Trajano y Adriano frente a los cristianos", ARYS 16 (2018) 289-332. 
de los cristianos como la vera religio veri Dei o verdadera religión del verdadero Dios, mientras que los cultos politeístas grecorromanos eran calificados de simples superstitiones dedicadas a los démones. ${ }^{78}$ Tertuliano habría así subvertido los significados, inspirándose en la crítica de la filosofía griega a la deisidaimonia. Al igual que habían dicho Teofrasto y Plutarco, temer a los démones era una religiosidad inferior propia de gente vulgar e inculta. Los cristianos no temían a los démones, a los que consideraban muy inferiores a su Dios. La diferencia radicaba en el hecho de que para Tertuliano todos los dioses eran démones, incluso el Apolo al que Plutarco servía. Por otra parte, adorar a un solo Dios, como hacían los cristianos, era un tipo de religiosidad monoteísta propia de la más elevada filosofía. Ahora bien, el uso por parte de Tertuliano de la palabra latina religio para definir al cristianismo suponía también una apuesta política, ya que calificaba al culto cristiano con la palabra que designaba el culto estatal romano. No se trataba, como en Hechos, de nostra religio, sino de la vera religio, es decir, la única posible. La religio oficial romana definida por Cicerón, en consecuencia, era para los cristianos una superstitio. El cristianismo no defendía como el resto de religiones de la Antigüedad su idoneidad para determinado tipo de personas frente a otras religiones menos idóneas, sino que negaba al resto su carácter de religiones, devaluándolas al rango de superstitiones. Y no lo hacía, como lo había hecho Cicerón, por considerarlas bárbaras en el sentido de extranjeras, ya que para el cristianismo no había extranjeros, puesto que todos - bárbaros y grecorromanos- podían cristianizarse, sino que lo hacía porque consideraba que eran cultos dirigidos no a dioses - ya que solo existía un Dios- sino a démones (los ángeles, como ya se vio en Colosenses, eran simples servidores enviados por Dios y no admitían culto de ninguna clase). Prueba del carácter político de la apuesta conceptual de Tertuliano es el hecho de que fuera él precisamente quien utilizó por primera vez el término Romanitas, como opuesto a Christianismus o Christianitas. ${ }^{79}$ Frente a la Ley romana, la Ley cristiana (el Evangelio), frente al culto al emperador (Divi Filius), el culto al crucificado por orden del emperador (Dei Filius).

78 Cf. Tertuliano, Apologeticum, 16.14; 24.1-2; 26.2.

79 Cf. Tertuliano, De Pallio, 4.1; aunque el término usado por Tertuliano fue, como hemos dicho, christianismus, ya que christianitas aparece por primera vez en el Código Teodosiano 12.1.112-123; 16.7.7. 
Poco después de Tertuliano, el abogado cristiano Minucio Félix (170-270 d.C. aprox.) utilizaba en el mismo sentido los términos superstitio y religio en su Octavio, ensayo en forma de debate en que el politeísta Cecilio era convertido por el cristiano Octavio. ${ }^{80}$ En cualquier caso, Tertuliano no añadió ningún matiz especial al concepto de religio que había acuñado Cicerón, que seguía interpretándose como culto sagrado.

Cipriano de Cartago, en cambio, sí lo hizo, otorgando un nuevo significado para la palabra religiosus al relacionar el adjetivo con la carrera eclesiástica, aunque no todavía con las creencias y la ética. ${ }^{81}$ Un religioso sería desde entonces un tipo de persona diferente de un laico. Hay que tener en cuenta que en el mundo griego y romano no existía esa diferencia y todos los ciudadanos podían desempeñar cargos sacerdotales en determinados momentos de su vida, como cualquier otro tipo de cargo político. Tampoco en el mundo judío el desempeño del culto se otorgaba de modo vocacional, sino que se nacía sacerdote al pertenecer al clan aarónida de la tribu de Leví. Por tanto, los cristianos habían creado un nuevo tipo de sacerdocio. Durante el Medioevo y hasta el siglo XVIII, la palabra religiones se usaría, además, para referirse a las distintas órdenes monásticas: religio benedictina, religio dominica, etc. Pero este uso se perdería y nada tiene que ver con el actual concepto de religión.

Poco antes del 313, Arnobio de Sica (255-327 d.C.), profesor de oratoria y filosofía en África, se convirtió al cristianismo y escribió Adversus nationes, en la que el término religio se convirtió en la palabra clave, utilizada en 90 ocasiones. ${ }^{82}$ Comenzó en 1.2.2-3 y 1.3.1 relacionando el concepto de Christianae religionis con los términos cultores, oratio y sacramenta, con lo cual, en principio, se mantuvo en la línea tradicional de definición de religio como culto; pero inmediatamente después (1.5.1-1.6.1), cuando defendía al cristianismo de las acusaciones de criminalidad que le atribuían los politeístas, utilizó religionis nostrae, incluyendo así no solo los ritos sino también las prácticas morales que se atribuían a los cristianos. La inclusión de la ética junto a los ritos en la categoría de religio debió producirse, en realidad, desde los orígenes del cristianismo e incluso en el judaísmo

\footnotetext{
80 Cf. Minucio Félix, Octavio, 1.5-7, 13, 26, 29 y 38.

81 Cf. Cipriano, Epistolae, 40.1.3; 55.8.2.

82 Cf. Arnobio, Adversus nationes, $1.25 ; 1.38 ; 1.57 ; 2.2 ; 2.70-72$.
} 
de habla latina, ya que en la Torá se mezclaban los mandamientos de tipo ritual y los de tipo ético sin distinción, mientras que en el mundo grecorromano la ética era cuestión de la filosofía, y el ritual, cuestión de la religión. Pero, como vimos, en la carta de Santiago se distinguía entre los aspectos puramente rituales y los puramente éticos, vinculando religio preferiblemente con la ética. Independientemente de que Arnobio hubiese o no leído dicha carta, lo cierto es que su argumentación va en la misma línea. Además, en 1.24.1, Arnobio relacionó lo religioso con las creencias y opiniones respecto de lo divino y, tras calificar de pueriles las creencias de quienes se dejaban arrastrar por los errores de los démones, añadió: vestra sunt inreligiose opinata et inreligiosius credita. Es decir, adjetivó las opiniones y creencias de los gentiles como irreligiosas, con lo cual estaba ampliando ya el campo semántico del término religio incluyendo también en él las creencias filosóficas. En 3.15.2, calificó los mitos de la religio politeísta de errores y ambigüedades. En 7.35.3, dijo que religiosum est credere y, en 7.37.2, que opinio religionem facit, o sea, que las creencias y opiniones hacen la religión. La palabra religio había adquirido ya el campo semántico de la fides o pistis, en sus diversos sentidos.

El cambio conceptual respecto a la categoría de religio usada por Cicerón es total: si en el orador republicano las creencias e ideas sobre los dioses eran algo completamente separado del culto oficial que todo buen ciudadano debía respetar, en Arnobio se unieron totalmente la cuestión del culto y de las creencias. Por otra parte, durante todo el tratado se refirió tanto a la religión cristiana como a la politeísta con el término religio (nostra y vostra) y cuando defendió al cristianismo de la acusación de superstitio, aparte de rechazar dicha acusación definió este concepto como un tipo de"religión execrable y nefasta, llena de impiedad y sacrilegio", es decir, ya no consideraba religio el culto oficial y superstitio el bárbaro como Cicerón, sino que otorgaba un sentido más amplio al término religio que incluía al de superstitio (1.25.3-4). Paradójicamente, del capítulo 4.16 .3 se deduce que Arnobio basaba sus críticas contra las creencias politeístas en la lectura de Ennio y Cicerón.

$Y$ eso es algo que caracterizaría también a su discípulo Lactancio (240-320 d.C., aprox.). Ambos profesaron muy probablemente en sus orígenes cierto escepticismo filosófico, quizás epicureísta, que los llevó a rechazar el culto a los dioses y a convertirse al cristianismo, precisamente en momentos complicados por la persecución 
de Diocleciano. Curiosamente lo hicieron después de separarse con motivo del nombramiento de Lactancio como rétor de la corte de Diocleciano en Nicomedia. Tras años denostado por su conversión, Lactancio se convirtió en tutor de Crispo, el primogénito del emperador Constantino, con lo cual su obra tuvo una gran repercusión en el siglo IV (a pesar de no profesar un catolicismo muy ortodoxo y apenas citar las Escrituras cristianas). En una ocasión utilizó el término religio de forma tradicional, aunque para referirse a los ritos politeístas. ${ }^{83}$ Sin embargo, ya en 1.20.20-21 había dicho:

Hay, pues, que cultivar la virtud, pero no una imagen de la virtud, y ha de ser cultivada, no con sacrificios, ni con incienso, ni con súplicas solemnes, sino solo con la voluntad y la intención: efectivamente, ¿qué otra cosa es cultivar la virtud sino comprenderla y sujetarla a nuestra alma?Y esto, en cuanto uno empieza a quererlo, lo consigue. Este es el único honor que se debe dar a la virtud, pues religio y veneración solo se debe dar al único Dios. ${ }^{84}$

Aunque el término es utilizado en el sentido de culto, el pasaje pretende precisamente consolidar el matiz semántico que lo relacionaba con la ética, tal como había hecho la carta de Santiago. En cuanto a la relación entre religión y sabiduría, comienza ya a poner en contacto ambas categorías en 1.1.7, para sentenciar en 1.1.25:"no se debe aceptar ninguna religión que no vaya acompañada de saber, ni se debe aprobar ningún saber que no vaya acompañado de religión", frase que implica fusionar religión y sabiduría. La misma idea se aprecia cuando explica que los filósofos habían llegado con su sabiduría a rechazar la falsedad de las religiones politeístas, pero habían alcanzado el conocimiento de la verdad; "Y, como esto sobrepasa las fuerzas de la condición humana, esa facultad de cumplir esta función nos fue concedida a nosotros los cristianos, a quienes Dios concedió la ciencia de la verdad" (2.3.25). Y, si la falsa religión politeísta, "al no tener preceptos que lleven a la justicia y a la virtud, ni enseña ni hace mejores a los hombres; por otro lado, la filosofía, al no identificarse con la religión, es decir, con la suma piedad, no es la autentica sabiduría" (4.3.2). En esta última sentencia, Lactancio condensaba los dos aspectos nuevos que se habían añadido al campo semántico de religio: ética y opiniones o creencias sobre lo divino. Un

\footnotetext{
83 Cf. Lactancio, Divinae Institutiones, 1.23.6-7.

84 Traducción de Eustaquio SÁnchez SALOR, Madrid, Gredos, 1990.
} 
poco más adelante, tras repetir una y otra vez que no se puede separar religión de sabiduría, dice:

De todas formas, la sabiduría está antes y la religión después, porque lo primero es conocer a Dios y lo segundo adorarle. De esta forma sucede que ambos términos tienen el mismo sentido, aunque parezcan ser cosas distintas: uno se basa en el conocimiento y otro en la acción, pero son semejantes a dos ríos que nacen de la misma fuente" (4.4.3).

Con lo cual, podríamos decir que la sabiduría es el medio por el cual se alcanzan las creencias en lo divino que, junto a las prácticas rituales y éticas, componen la religión. Si la sabiduría es una categoría conceptual diferente es porque ella es la que permite alcanzar los conocimientos, pero no solo los que conciernen a lo divino, sino todo tipo de conocimientos.

Con respecto al concepto de superstición no es original, sino que al igual que Tertuliano considera que equivale a falsa religión (4.28.616), es decir, al culto a los démones. Esta última cuestión, la desarrolla mucho más que Tertuliano, dedicándole la parte fundamental del libro segundo (2.14-17), aunque ya en 1.7.5-11 había explicado la diferencia entre Dios, los ángeles o ministros de Dios, y los démones, a los que atribuía en 1.15 un origen humano, como Ennio y Evémero.

Sin embargo, en el mismo lugar donde hablaba del concepto de superstición inventó una falsa ${ }^{85}$ etimología de religio derivándola de religare:"Nacemos, en efecto, con esta condición: para ofrecer al Dios que nos ha engendrado el justo y debido culto, para conocerle a él solo y seguirle. Con este vínculo de piedad estamos atados y ligados a Dios: de ahí el término religio, que no toma su significado, como interpreta Cicerón, de relegere" (1.28.2-3). Se trata de un giro total al concepto aludiendo a la vinculación del individuo con la divinidad. Por tanto, no solo se rompe con el límite que Cicerón había puesto a la categoría religio de prácticas rituales, sino también con el de prácticas de tipo público, reivindicando una religiosidad más privada.

Todo lo contrario podemos apreciar en un griego contemporáneo de Lactancio y vinculado como él al emperador Constantino, Eusebio de Cesarea (265-339 d.C.), que definió el cristianismo como una politeuma eusebeias y como una tis philosophia, incorporando así

85 Respecto a la imposibilidad filológica de derivar religio de religare, cf. Emile BENVENISTE, Vocabulario, 400-401. 
no solo las creencias e ideas al término christianismós junto a piedad religiosa y ética, sino también aspectos políticos (como una "ciudadanía de piedad"); lo cual no significa — como defendió Boyarin en sus primeras reflexiones al respecto- que crease un nuevo concepto de "religión", puesto que para referirse al culto siguió usando threskeia de la forma tradicional, en todo caso con los matices añadidos en el Nuevo Testamento. ${ }^{86}$ Evidentemente, en este giro de la religión personal de aquel Lactancio de las persecuciones de Diocleciano a la religión política de Eusebio, tiene mucho que ver la celebración del Concilio de Nicea presidido por Constantino, un encuentro que Eusebio describió como si el Reino de Dios hubiese llegado.

De hecho, el matiz personalista del término religio — que quizás esté imponiéndose en la sociedad individualista contemporánea-, no triunfaría en el siglo IV a pesar del Imperio Cristiano -o precisamente por la cristianización del Imperio-, como demuestra una ley (Digesto 1.8.6.) del Emperador Marciano de Constantinopla (350-357 d.C.) que definía lo sagrado (res sacrae) como aquello que había sido consagrado en el espacio público (publicae consacratae sunt), y no en el privado (non privatae), ya que, si un individuo quería hacer algo sagrado en privado (privatim), ese hecho no era sacro, sino profano (sacrum non est, sed profanum).Y la religión, indiscutiblemente, estaba orientada hacia lo sagrado, no hacia lo profano.

Sin embargo, Agustín de Hipona (354-430 d.C.) definió la religio como un impulso natural del ser humano que lo llevaba a adorar a la divinidad, admitiendo que la palabra también podía aplicarse a familiares y amigos. ${ }^{87}$ Hay algo de arcaizante en su definición, propia de un hombre culto que había leído a los clásicos, ${ }^{88}$ pero también hay una curiosa reivindicación del individualismo, quizás porque en tiempos de san Agustín se produjeron las primeras invasiones bárbaras y el catolicismo se vio separado del Estado en los principados

86 Cf. Eusebio de Cesarea, Demonstratio evangelica, 1.2.10. Respecto al uso de threskeia: Vita Constantini, 3.53; Praeparatio Evangelica, 2.3.106; Historia Ecclesiastica, 10.5. Cf. Daniel Boyarin, Border Lines. The Partition of Judaeo-Christianity, Philadelphia, University of Pennsylvania Press, 2004, 205.

87 Cf. Agustín de Hipona, Civitate Dei, 10.1.392; De vera religione, 107-10.

88 De hecho, en ningún momento incorpora Agustín las creencias al concepto de religio, por lo que hay que rechazar la idea de que fue él quien acuñó la moderna categoría conceptual, como defendió William CAvanaugh, The Myth of Religious Violence: Secular Ideology and the Roots of Modern Conflict, Oxford, Oxford University Press, 2009, 62-64. 
arrianos de los pueblos germánicos. En cualquier caso, dado que este fenómeno sería pasajero y los germanos acabarían por convertirse al catolicismo, lo cierto es que la religio sería una cuestión de Estado durante todo el Medioevo y durante las Guerras de Religión de los siglos XVI y XVII (cuius regio, eius religio), y solo a partir de la Ilustración se reivindicaría el carácter individualista de la religión, en un momento en que - por primera vez en la Historia — se decidió separarla del Estado, creando una nueva categoría de laicismo que sin duda influyó en el concepto moderno de religión, otorgándole los últimos matices que conforman su actual campo semántico.

Pero durante los catorce siglos que van desde la difusión de la Vulgata hasta la Revolución Francesa, los pueblos cristianos que escuchaban la lectura de las Sagradas Escrituras en latín durante la celebración de la eucaristía, tuvieron una conceptualización del término derivada de la forma en que Jerónimo de Estridón lo introdujo en su Biblia. Ya se vio cómo se concebía religio en la Vetus Latina, traduciendo la threskeia del Nuevo Testamento, que podríamos resumir de la siguiente forma uniendo el uso que de la palabra hacían Colosenses, Hechos y Santiago: acciones prácticas rituales orientadas al Dios único, diferentes de otros cultos orientados a ángeles y demonios de carácter supersticioso, así como acciones prácticas de carácter ético presididas por el mandamiento único del amor al prójimo. San Jerónimo ni modificó ni añadió nada al respecto en su Nuevo Testamento, donde la palabra aparece las mismas cuatro veces.

Sin embargo, en el Antiguo Testamento, donde no se usaba la palabra threskeia, introdujo el término religio ocho veces: Éx 12,26, 12,43 y 29,9; Lev 7,36 y 16,31; Núm 19,2; Est 8,17 y 9,27. Curiosamente, en total suman doce. Evidentemente, detrás de su uso había un bagaje cultural que tenía como precedentes a Tertuliano, Arnobio y Lactancio y que tendía a armonizar Nuevo y Antiguo Testamento. El tema es, sin duda, de gran importancia, dado que el pueblo analfabeto $(90 \%$ de la población —o más - en el Medioevo) no leería a los Padres de la Iglesia, pero sí escucharía la Vulgata de Jerónimo en la misa, con lo cual esta sería la versión de la categoría religio que se popularizaría y que pasaría a las lenguas romances y germánicas.

Hay dos pasajes en los que no disponemos de versiones diferentes en la Vetus Latina: Éx 12,43 y Lev 7,36. En ambos, Jerónimo utilizó el término religio para traducir la palabra hebrea תn, huqqat (vó $\mu$ os, 
"normativa", en los LXX) ${ }^{89}$ El término se utiliza de forma claramente tradicional, para referirse a un ritual. Se trata de casos peculiares, porque generalmente los traductores de los LXX no utilizaban nomos

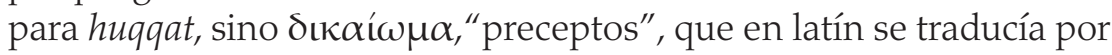
caeremonias o praecepta, refiriéndose siempre a preceptos relativos al culto sagrado. ${ }^{90}$ La palabra nomos se utilizaba más a menudo para traducir הרֶוֹ, Torah, "Ley". Para las normas morales y rituales que tenían que cumplir en la vida diaria los judíos se usaba תִִ̣ mitswot ( $\varepsilon \nu \tau 0 \lambda \varepsilon ́ s$, mandata, "mandamientos"). Había en definitiva tres palabras en hebreo bíblico para aludir a normas: Torah, para la Ley en sentido amplio y general; huqqat, para los preceptos relativos al culto; y mitswot, para los preceptos morales y rituales de la vida cotidiana. ${ }^{91}$ Jerónimo tradujo Éx 12,43 así: Dixitque Dominus ad Moysen et Aaron: Hæc est religio Phase: omnis alienigena non comedet ex eo ("El Señor dijo a Moisés y a Aarón: Este es el rito de la Pascua. Ningún extranjero la comerá"). $9{ }^{92}$ En los siguientes versículos se aclaraba que para que un extranjero o un esclavo participasen de la fiesta, era necesaria previamente su circuncisión. Se relacionaba aquí religio con un ritual festivo sacro. En cuanto a Lev 7,36-37, lo tradujo así: Et quæ præcepit eis dari Dominus a filiis Israel religione perpetua in generationibus suis. Ista est lex holocausti et sacrificii pro peccato atque delicto et pro consecratione et pacificorum victimis. ("Y esto es lo que mandó el Señor que les diesen los hijos de Israel como religio perpetua en sus generaciones. Esta es la ley del holocausto y del sacrificio por la expiación del pecado y del

89 La Vetus Latina, en general, sigue más a los Setenta que a la Vulgata. Cf. SABATIER, Bibliorum, v. I, p.V.

90 Cf. Gén 26,5; Éx 12,14; 12,17; 12,43; 13,10; 27,21; 28,43; 29,9; Lev 3,17; 7,36; 10,9; 16,$29 ; 16,31 ; 16,34 ; 17,7 ; 18,3-5 ; 18,26 ; 18,30 ; 19,19 ; 19,37 ; 20,8 ; 20,22 ; 20,23$; 23,14; 23,21; 23,31; 23,41; 24,3; 25,18; 26,3; 26,15; 26,43; Núm 9,3; 9,12; 9,14; 10,$8 ; 15,15 ; 18,23 ; 19,2 ; 19,10 ; 19,21 ; 31,21 ; 35,29 ;$ Dt 6,$2 ; 8,11 ; 10,13 ; 11,1 ; 28,15$; 28,$45 ; 30,10 ; 30,16 ; 2$ Sam 22,23; 1 Re 2,3; 3,3; 6,12; 9,6; 11,11; 11,33; 11,34; 11,38; $2 \operatorname{Re} 17,13 ; 17,19 ; 17,34 ; 23,3 ; 1$ Cro 29,19; 2 Cro 7,19; Sal 18,22; 89,31; 119,16; Job 38,33 ; Jer 5,24; 10,3; 33,25; 44,23; Ez 5,6-7; 11,20; 18,9; 18,17-19; 18,21; 20,11-13; 20,16; 20,19; 20,21; 20,24; 33,15; 37,24; 43,11; 43,18; 44,5; 44,24; 46,14; Miq 6, 16 .

91 Véase por ejemplo el uso de estos términos hebreos, griegos y latinos en Gén 26,5:" Porque Abrahán me obedeció y guardó mi observancia, mis mandamientos

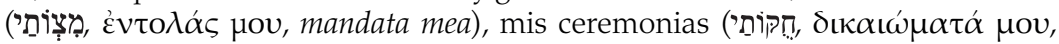

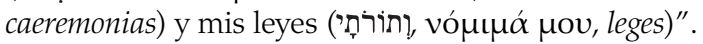

92 Traducción de Luis AlONSO ScHÖKEL, Biblia del peregrino, Ed. Ega, Bilbao, 1996, v. I, 181-182. 
delito y por la consagración y por las víctimas de los pacíficos" $).{ }^{93}$ Aquí utiliza religio para referirse al ritual de sacrificio que los hijos de Israel debían ofrendar a los sacerdotes de la estirpe de Aarón en el holocausto. En ambos casos, el sentido de religio es el de precepto ritual.

En la misma línea que los dos pasajes anteriores se sitúan otros dos en los que igualmente se traduce huqqat por religio, pero de los que ya tenemos versiones diferentes en la Vetus Latina: Lev 16,31 y Núm 19,2. Jerónimo tradujo así el pasaje del Levítico: Sabbatum enim requietionis est, et affligetis animas vestras religione perpetua ("El sábado evidentemente es de descanso, y afligiréis vuestras almas en perpetua religio").${ }^{94}$ Este texto se refiere, como explica anteriormente el versículo 29, al décimo día del mes séptimo, elYom Kippur, que debía ser día de aflicción. Frente a la interpretación de huqqat como vó $\mu$ ноv

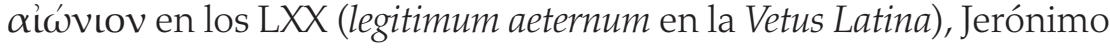
introdujo religione perpetua para referirse a este ritual festivo. Es decir, huyó de términos vinculados a lo normativo para inclinarse de nuevo por la"religión perpetua".

Núm 19,2: Ista est religio victimae, quam constituit Dominus. Praecipe filiis Israel, ut adducant ad te vaccam rufam aetatis integrae, in qua nulla sit macula, nec portaverit jugum. "Esta es religio de una víctima que ha ordenado el Señor. Manda a los hijos de Israel que te traigan una vaca roja de edad íntegra, que no tenga ninguna mancha

93 Traducción propia. ScHÖKeL, Biblia del peregrino, v. I, 238, aquí traduce primero por "ley perpetua" en el versículo 36 y luego por "rito del holocausto" en el 37, invirtiendo los términos del texto hebreo, que utiliza huqqat en el 36 y torah en el 37. Los LXX utilizaban nomos en ambos casos.

94 Sabatier no menciona aquí ningún pasaje alternativo, pero sí lo hay, como se aprecia en Vetus Latina Database que menciona la versión del Codex Lugdunensis (ss. VI-VII): Sabbata sabbatorum erit haec requietio erit vobis ea; tribulate animas vestras, legitimum aeternum. Este códice de la Vetus Latina, integrado por los manuscritos latinos 403 y 1964 de la Biblioteca Municipal de Lyon, es considerado por Vetus Latina Database como versión Itala, aunque quizás fuera Hispana, como defendió Teófilo Ayuso, "Origen español del Códice Lugdunense de la Vetus Latina", separata de Estudios Bíblicos, Madrid, 1953. Como es habitual, sigue a los

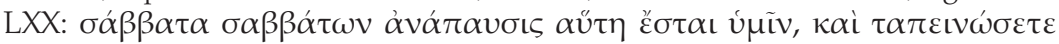

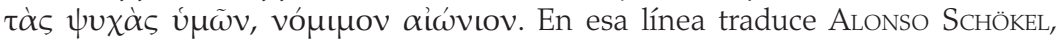
Biblia del peregrino, v. I, 255: "Es el sábado solemne en que haréis penitencia: es ley perpetua". 
ni haya llevado yugo".$^{95}$ Frente a la traducción griega del hebreo hu-

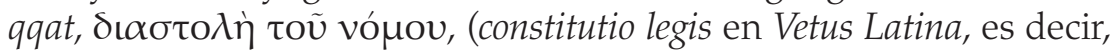
"preceptos de la ley"), Jerónimo introdujo religio victimae con lo cual hizo de nuevo a religio equivalente a"rito", concretamente al sacrificio ritual de la vaca roja.

Además de alejarse de las connotaciones legislativas que tenían las traducciones de los LXX y la Vetus Latina, es posible que Jerónimo optara por religio en estos cuatro pasajes para traducir huqqat porque notaba por el contexto que en los cuatro casos se trataba de tabúes religiosos inviolables: la Pascua que no se podía violar con la presencia de incircuncisos, la carne del holocausto que no podía ser comida nada más que por los sacerdotes, el sábado del Yom Kippur que no debía ser violado por ningún israelita, y la vaca roja que no debía tener tacha ni haber estado bajo el yugo. Es como si Jerónimo echase de menos en estos cuatro casos la palabra threskeia, inexistente en los LXX, que — como ya se vio- incluía en su campo semántico ese matiz de tabú o escrúpulo religioso.

A continuación, se analizarán aquellos pasajes en los que la introducción del término religio por parte de Jerónimo no solo es notoriamente diferente a la de la Vetus Latina y los LXX, sino que aporta otros sentidos al término latino.

La primera vez que aparece el término religio en el Pentateuco de Jerónimo es en boca de Moisés, anunciando a su pueblo la muerte de los primogénitos de Egipto y la salvación de los israelitas por virtud del sacrificio pascual. Ex 12,26-27a: Et cum dixerint vobis filii vestri: Quae est ista religio? Dicetis eis: victima transitus Domini est ("Y cuando os digan vuestros hijos: ¿qué religio es esta? Les diréis: es la víctima del tránsito del Señor"). ${ }^{96}$ Jerónimo no solo sustituyó "el sacrifi-

95 Traducción propia. De nuevo la Vetus Latina sigue más bien a los LXX. Códice Lugdunense: Haec est constitutio legis quem constituit Dominus, dicens: Loquere filiis Israhel et accipiant a te vitulam rufam sine vitio, quae non habet in se repraehensionem

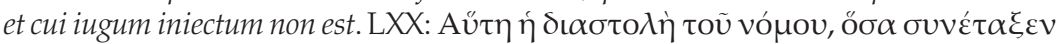

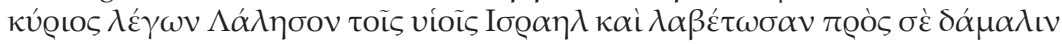

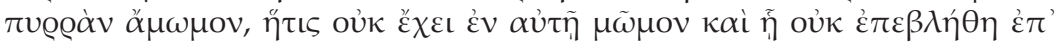

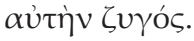

96 Traducción propia. La versión de la Vetus Latina es más fiel al original hebreo: Et erit cum dicent ad vos filii vestri: Quae est servitus ista? Immolatio Pascha hoc Domino. Para el Pentateuco, Sabatier utilizó la edición de José María CARO, Roma, 1688, basada en los manuscritos S. Pauli, Orat. B.VI. B.VII y Vaticanus 4220. Cf. SABATIER, Bibliorum, v. I, 133. Otra variante aparece en la Vetus Latina Itala: deservitio en 
cio de la Pascua" por "el tránsito del Señor", que podía interpretarse doblemente como el paso del ángel de la muerte durante la Pascua y como una alusión profética a la primera venida de Cristo, ${ }^{97}$ sino que introdujo el término religio. En el texto hebreo aparecía la palabra

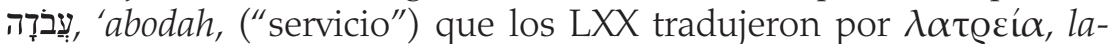
treia ("adoración"). 'Abodah — como ya se ha dicho- es una palabra perteneciente al campo semántico de la servidumbre, por lo que es evidente que hacía alusión al servicio religioso. Obviamente, aquí la Vetus Latina respetó más el sentido original del texto hebreo que los LXX y que Jerónimo. La introducción del término religio por parte de este se podría justificar por su relación con"ritos sagrados" siguiendo la interpretación ciceroniana, ${ }^{98}$ pero también podría tener el sentido de "misterio" religioso relacionado con la encarnación y sacrificio de Cristo, dada la interpretación del sacrificio del cordero pascual como rito alegórico de la crucifixión, en que se sacrificó al Cordero Místico. Nótese que este pasaje se haya muy próximo al ya comentado de Éx 12,43. Podría pensarse que el escriba hebreo, al usar 'abodah en Éx 12,26 y huqqat en Éx 12,43 para referirse a la Pascua, lo hizo como si ambos términos fueran sinónimos, pero en realidad no hay que perder de vista el matiz diferenciador: 'abodah era el servicio religioso y huqqat la normativa que regulaba dicho servicio. Al introducir religio en Éx 12 para traducir tanto 'abodah como huqqat, Jerónimo le otorgaba ambos sentidos a la palabra latina, tanto el de servicio sagrado como el de normativa al respecto, ampliando así su campo semántico. Por otra parte, el hecho de que corrigiese a los LXX de forma muy diversa a la Vetus Latina y decidiese introducir el término religio por primera vez en la Vulgata en ese momento fundacional del judaísmo podría indicar cierto respeto del santo hacia los judíos y un deseo de vincular claramente la religión cristiana con la judía.

lugar de religio o servitus, al igual que san Agustín, Locutionum in Heptateuchum, 2,66 (Cf. Vetus Latina Database).

97 El término transitus se utilizaría para explicar la encarnación del Logos pasando desde Dios Padre a través de la tercera persona de la Trinidad, el Espíritu, generando así el problema teológico del Filioque, tan relevante en los primeros Concilios de Toledo, que supondría la ruptura entre la Iglesia Católica y la Ortodoxa. Aunque en tiempos de Jerónimo aún no se había desarrollado este debate, la especulación trinitaria estaba en plena efervescencia y tendría, entre otras, esta consecuencia.

98 AlONSO SCHÖKEL, Biblia del peregrino, v. I, 179, de hecho, traduce por"rito". 
En cuanto a Éx 29,9, lo tradujo así: Aaron scilicet et liberos eius, et impones eis mitras: eruntque sacerdotes mihi religione perpetua. Postquam initiaveris manus eorum ("Y por supuesto, les impondrás la mitra a Aarón y a sus hijos: ellos serán para mí sacerdotes en la religión perpetua. Después iniciarás sus manos" $).{ }^{99}$ Aparte de utilizar el verbo initiare, de reminiscencias mistéricas, Jerónimo corregía a la Septuaginta, que se había saltado תrọ (huqqat con el prefijo preposicional lamed), un error seguido en la Vetus Latina, que tiene importantes repercusiones, ya que implica atribuir la perpetuidad al sacerdocio, en lugar de asignarla a la normativa sagrada. El texto hebreo decía"y será para ellos el sacerdocio por huqqat perpetua". Para recalcar el error de la Septuaginta —intencionado o no-, Jerónimo modificaba sacerdotium por sacerdotes y dejaba el pronombre personal (que en hebreo también iba con lamed, pero era de tercera plural en vez de primera singular, cambio ya realizado en los LXX y en la Vetus Latina) en dativo y religione perpetua en ablativo. Pero, además, como consecuencia de este cambio, el sacerdocio aarónida dejaba de ser perpetuo y solo la religio de Dios adquiría el carácter eterno. La interpretación más correcta del texto hebreo era que el sacerdocio se había entregado al clan aarónida por una normativa sagrada de carácter eterno e inviolable. Pero después del 70 d.C. ya no hubo templo ni sacerdocio, de modo que el decreto se salvaba entendiendo huqqat como el objeto del calificativo que otorgaba la eternidad.Y Jerónimo tradujo entonces de nuevo huqqat por religio porque ningún decreto religioso debía ser tan eterno como la propia religión. La religio del Segundo Templo había desaparecido, pero la religión cristiana, que reivindicaba su carácter de Verus Israel, cumpliría el oráculo de Yahvé manteniéndose para siempre. Sin duda la traducción de este pasaje le daba a Jerónimo una buena oportunidad para lucirse y hacer una sutil apología del cristianismo. Por otra parte, leyendo la Vulgata desde los siglos posteriores, el término religio se vinculaba aquí con el clero, en la línea iniciada por Cipriano de Cartago, al menos en el Medioevo. Pero también se entendería simplemente como "religión" en el sentido contemporáneo del término, que se impondría al

99 Traducción propia. El ya mencionado Códice Lugdunense decía: et erit eis sacer-

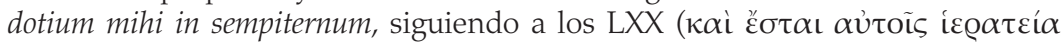

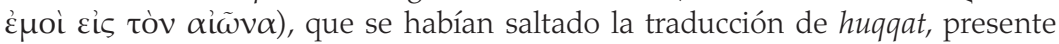

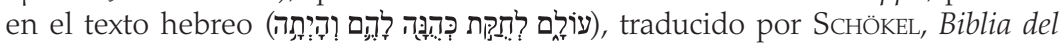
peregrino, v. I, 209: "El sacerdocio les pertenece por derecho perpetuo". 
clerical. Por tanto, se trata de un pasaje relevante para comprender la evolución de la idea de religio.

Más expansiva aún es la traducción por parte de Jerónimo del pasaje de Est 8,17: Apud omnes populos, urbes, atque provincias, quocumque regis iussa veniebant, mira exultatio, epulae atque convivia, et festus dies: in tantum ut plures alterius gentis et sectae eorum religioni et caeremoniis iungerentur ("Así pues, en todos lo pueblos, ciudades y provincias, donde quiera que llegaban las órdenes del rey, hubo maravillosos regocijos, celebraciones, banquetes y días de fiesta: en tanto grado que muchos de otras naciones y sectas abrazaron su religio y sus ceremonias"). ${ }^{100}$ Por una parte, Jerónimo suprimió toda alusión a los judíos dejando así la conversión de los gentiles a la religión de Dios como una cuestión más abierta e incluyente, de modo que el pasaje se pudiera utilizar también como ejemplo de conversión al cristianismo. Por otra parte, no solo añadió el término religio, que en esta ocasión no correspondía a ninguna palabra hebrea o griega, sino también el de secta, eliminando por el contrario el verbo iudaizare, transcripción casi literal que realizan los traductores de la Vetus Latina del griego 'Iov $\alpha \alpha i \zeta \omega$, que los LXX utilizaron aquí para traducir el par-

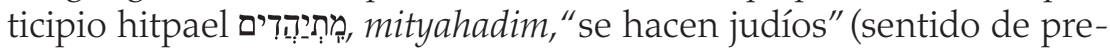
sente reflexivo), palabra que solo aparece en esta ocasión en la Biblia.

100 Traducción propia. Un texto muy diferente al de la Vetus Latina que era aquí más fiel a los Setenta y al original hebreo. En la versión del Codex Corbeiensis $\mathrm{n}^{\circ} 7$ (en torno al 500 d.C.): Secundum civitatem et regionem, ubicunque propositum erat exemplum epistolae, gaudium et volutas; et multis gentilium circumcidebant se et iudaizabant, propter timorem qui factus erat adversus inimicus iudaeorum; destacando la frase final: "Y muchos se circuncidaban y judaizaban, por el temor de lo que se había hecho contra los enemigos de los judíos"; Cf. SABATIER, Bibliorum, v. I, 791. Versión ligeramente diferente (no añade eso de"lo que se había hecho contra los enemigos de los judíos") en el Codex Monacensis: epulatio et convivium per civitates et regiones ubicumque propositum erat edictum. Et multi gentilium circuncidebantur et iudaizabunt propter metum iudeorum (Cf. Vetus Latina Database); que sigue más

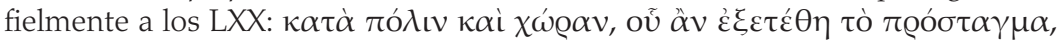

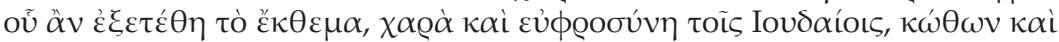

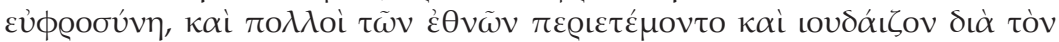

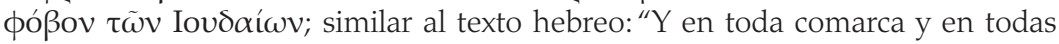
las ciudades, donde había llegado el edicto del rey, los judíos festejaron con banquetes y alegría, y muchos de entre los pueblos de la tierra se tornaron judíos

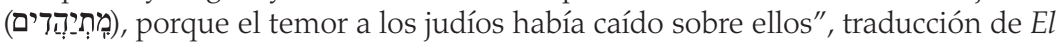
libro de Ester. Edición bilingüe con nueva traducción, comentario y notas del Rabino Manes Kogan, Ed. Masortí Olamí, 2014, 31. 
Se trata, evidentemente de un neologismo creado en el contexto histórico del helenismo, probablemente en época asmonea, ya que fue a partir de la expansión asmonea cuando comenzó a darse un fenómeno de judaización importante. En 2 Macabeos, escrito originalmente

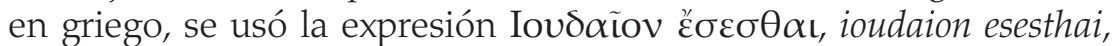
"hacerse judío" (2 Mac 9,14-17), que probablemente era traducción

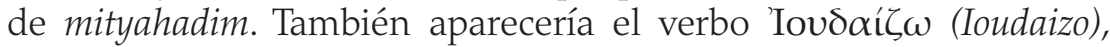

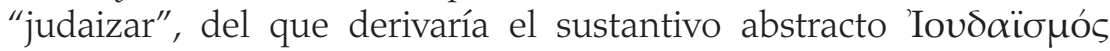
(Ioudaïsmós), "judaización". ${ }^{101} \mathrm{Si}$ en los tiempos de redacción de 2 Macabeos no existía la categoría conceptual moderna de religión, tampoco existía la categoría actual de judaísmo. Ioudaïsmós significaba simplemente "acción a favor de los judíos" o "actuar como judío". Hacerse judío, como fantasiosamente atribuye el autor de 2 Macabeos a Antíoco IV en su lecho de muerte en el pasaje citado, no consistía en cambiar de religión, tal como hoy lo entendemos, sino en cambiar de nacionalidad, de etnia, de ciudadanía. Y el primer paso para hacerse judío, como añaden los LXX en este fragmento de Esther, era circuncidarse. Frente a circuncisión y judaización, Jerónimo habla simplemente de asistir a las ceremonias judías, que era lo que tras la destrucción del Templo hacían los "temerosos de Dios" en las sinagogas. Evidentemente, Jerónimo eliminó la palabra "judaizar" del texto por motivos obvios derivados de la teología católica de raíz paulina. Pero no solo sustituyó la circuncisión por las ceremonias, sino que añadió la palabra sectae y la expresión religioni iungerentur, es decir, "cambiar de religión". La palabra sectae se aplicaba en los siglos I y II a diferentes tendencias filosóficas, es decir, a gentes que - aún teniendo la misma religio — profesaban creencias diferentes. El caso claro son las sectas, haereses o filosofías que Josefo distinguía entre los judíos: fariseos, esenios y saduceos tenían la misma religio (el culto templario a Yahvé según la huqqah de la Torá),

101 Como derivaba 'E $\lambda \lambda \eta v$ เouós (Helenismós), "helenización", de 'E $\lambda \lambda \eta v i ́ \zeta \omega$ (he-

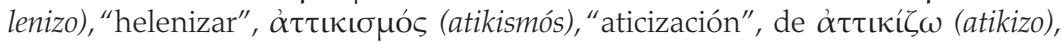

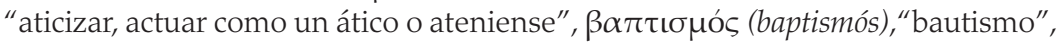
de $\beta \alpha \pi \tau i \zeta \omega$ (baptizo), "bautizar". Cf. Steve Mason, "Jews, Judeans, Judaizing, Judaism: Problems of Categorization in Ancient History", Journal for the Study of Judaism 38 (2007) 457- 512; Pedro Giménez de ArAGón, "Helenización del judaísmo y judaización del helenismo", en Gonzalo Cruz Andreotti, Tras los pasos de Momigliano. Centralidad y alteridad en el mundo greco-romano, Barcelona, Bellaterra, 2019, 57-86. 
pero diferentes creencias (los dos primeros grupos creían en la vida después de la muerte y en los ángeles mientras que los saduceos no). Al conectar aquí secta con religio, Jerónimo estaba conceptualizando la religión en un sentido más amplio, propio ya del siglo IV, que incluía las creencias. Por otra parte, en esa época, como se ha visto en el caso de Arnobio y Lactancio, uno podía religioni iungerentur (cambiar de religión) sin cambiar de nación. Tanto el maestro como el discípulo siguieron considerándose orgullosamente romanos al mismo tiempo que se hacían cristianos. Lejos quedaba ya la oposición entre Romanitas y Christianitas de Tertuliano. Para ellos y -a partir de Constantino - para todos los habitantes del Imperio, era compatible ser ciudadano romano y miembro de una u otra religión. Después del cierre de los templos politeístas por parte de Teodosio, a finales del siglo, ya no sería compatible, y con el tiempo se produciría la equivalencia entre los términos católico, apostólico y romano. Pero Jerónimo comenzó a traducir su Vulgata cuando todavía era posible una ciudadanía con libertad religiosa, algo que tardaría mil cuatrocientos años en volver a lograrse en Europa. Aunque no era el sentido del texto hebreo de Esther (en el que judaizar significaba cambiar de ciudadanía), ni la pretensión de Jerónimo (cuyo objetivo era desvincular la conversión al cristianismo de la ciudadanía judía o de cualquier otra), lo cierto es que con su traducción creó el precedente para que se considerase la religión como una cuestión separada de la nacionalidad o pertenencia a un Estado.

Un poco después Jerónimo introdujo de nuevo el término latino en el mismo sentido de "cambio de religión", pero en este contexto, sin embargo, mantuvo la palabra "judíos". ¿Por qué ahora sí? Porque el pasaje estaba vinculado a la celebración de la fiesta de Purim, y los cristianos no la celebraban. El texto original hebreo decía:“Los judíos aceptaron y se comprometieron, ellos y todos los de su simiente y todos los que se les iban uniendo, sin falta, a observar estos dos días, conforme a lo escrito, y en sus respectivas fechas, año tras año" (Est 9,27); y Jerónimo tradujo la parte central de la frase de la siguiente manera: susceperunt iudaei super se et semen suum, et super cunctos qui religioni eorum voluerunt copulari, ("se comprometieron los judíos y su semilla, y todos los que quisieron unirse a su religio"). ${ }^{102}$

102 Traducción del texto hebreo: El libro de Ester. Edición bilingüe con nueva traducción, comentario y notas del Rabino Manes Kogan, p. 36. Traducción propia del texto 


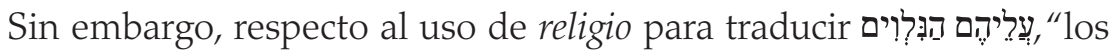
que se les iban uniendo", hay que tener en cuenta que esta misma

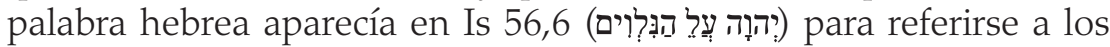
extranjeros que se unían a Yahvé, a los que"traeré a mi Monte Santo, los alegraré en mi casa de oración; aceptaré sobre mi altar sus holocaustos y sacrificios; porque mi casa es casa de oración, y a mi casa la llamarán todos los pueblos Casa de Oración" (Is 56,7) y "de entre ellos escogeré sacerdotes y levitas" (Is 66,21). ${ }^{103}$ Aunque el Tritoisaías (en torno al 500 a.C.) no desarrolló la cuestión de cómo se integrarían en el futuro mesiánico aquellos gentiles temerosos de Dios, todo indica que sería circuncidándose, como en el resto de la Biblia judía. Ahora bien, el hecho de que Dios prometiese crear para ellos un colegio propio de sacerdotes y levitas (obviamente no pertenecientes a la tribu de Leví ni al linaje aarónida), parece indicar que mantendrían su nacionalidad, con lo cual en la visión del Tritoisaías ya se preveía la posibilidad de conversión al culto a Yahvé de otros pueblos sin necesidad de que cambiasen de ciudadanía. Es un tema poco claro que supondría debates de interpretación importantes entre los propios judíos; por ejemplo, el existente al respecto entre Hillel y Shammay, pero también entre los judeocristianos, como fue el caso del debate entre Pablo y los cristianos de Jerusalén de origen fariseo mencionados en Hch 15 (el denominado Concilio de Jerusalén). Pero todo apunta a que Jerónimo concebía ya el cambio de religio como una transformación ética, ritual y de creencias que no implicaba el cambio de ciudadanía, sentido primitivo del texto de Esther, aplicable por ejemplo a los idumeos e itureos judaizados en época asmonea.

Recapitulando, Jerónimo introdujo la palabra religio en su Vulgata en doce ocasiones: traduciendo cinco veces np?, huqqat, "normativa sagrada"(Éx 12,43 y 29,9; Lev 7,36 y 16,31; Núm 19,2), una vez a עִבְְָ

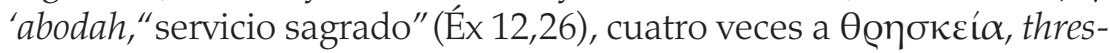
keia, "culto" (Hch 26,5; Col 2,18; Sant 1,26 y 1,27), y dos veces introduciéndola en el texto sin traducir ninguna palabra hebrea o griega

latino de Jerónimo. Aquí la Vetus Latina Itala (Códice Monacensis) dice tan solo: Et dies mentionis facientes per progeniem et patriam et civitatem et regionem, resumien-

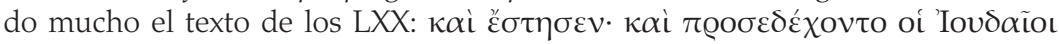

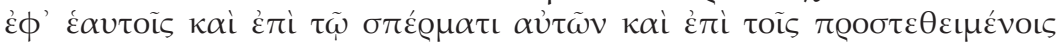

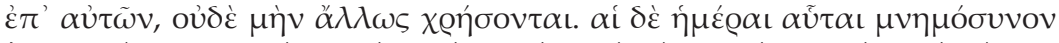

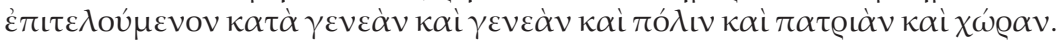

103 Traducción de AlONSO SchÖKeL, Biblia del peregrino, v. II, 160 y 179. 
determinada (Est 8,17 y 9,27). El resultado es que religio en la Vulgata de san Jerónimo es un término que corresponde no solo a las prácticas rituales sino también a las prácticas éticas y a las creencias sobre lo divino. Además, el cambio de religio no suponía ya un cambio de ciudadanía.

Para terminar, hay que concluir diciendo que ni huqqat ni threskeia ni ninguna otra palabra hebrea o griega, ni siquiera religio hasta el siglo IV, eran categorías que incluyesen en su campo semántico las creencias sobre lo divino. Solo a partir del sigloV y por influencia del latín cristiano, el griego comenzaría a entender la threskeia en un sentido más amplio. En cuanto al hebreo, habría que esperar hasta el Medioevo para que introdujera un término que definiera el judaísmo, , יִהָדוּר yahadut, y hasta el siglo XIX para que asignara a la palabra dat, los significados del concepto europeo de "religión". Por tanto, a la hora de traducir los términos hebreos, griegos y latinos tratados en este artículo en textos anteriores al siglo $\mathrm{V}$, no se debe hacer por la palabra "religión" para no cometer un grave anacronismo. En el mundo antiguo las creencias no eran asunto religioso, sino filosófico, y se admitía que personas que practicaban la misma religio tuvieran diferentes creencias sobre lo divino. 